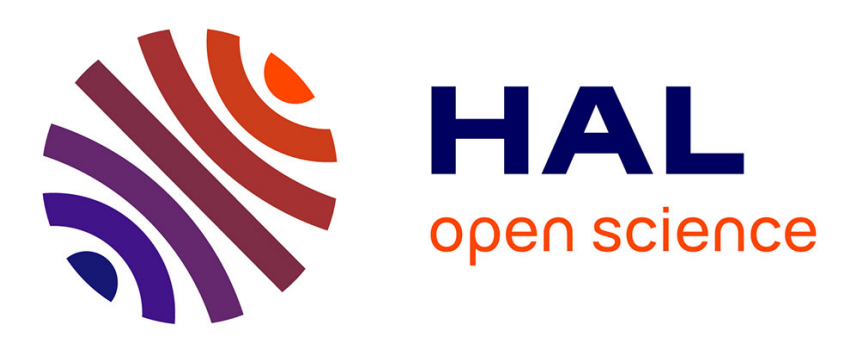

\title{
The high-resolution far-infrared spectrum of methane at the SOLEIL synchrotron
}

Vincent Boudon, Olivier Pirali, Pascale Roy, Jean-Blaise Brubach, Laurent

Manceron, Jean Vander Auwera

\section{- To cite this version:}

Vincent Boudon, Olivier Pirali, Pascale Roy, Jean-Blaise Brubach, Laurent Manceron, et al.. The high-resolution far-infrared spectrum of methane at the SOLEIL synchrotron. Journal of Quantitative Spectroscopy and Radiative Transfer, 2010, 111 (9), pp.1117-1129. 10.1016/j.jqsrt.2010.02.006 . hal00455999

\author{
HAL Id: hal-00455999 \\ https://hal.science/hal-00455999
}

Submitted on 11 Feb 2010

HAL is a multi-disciplinary open access archive for the deposit and dissemination of scientific research documents, whether they are published or not. The documents may come from teaching and research institutions in France or abroad, or from public or private research centers.
L'archive ouverte pluridisciplinaire HAL, est destinée au dépôt et à la diffusion de documents scientifiques de niveau recherche, publiés ou non, émanant des établissements d'enseignement et de recherche français ou étrangers, des laboratoires publics ou privés. 


\title{
The high-resolution far-infrared spectrum of methane at the SOLEIL synchrotron ${ }^{\text {th }}$
}

\author{
V. Boudon ${ }^{a, *}$, O. Pirali ${ }^{b, c}$, P. Roy ${ }^{b}$, J.-B. Brubach $^{b}$, L. Manceron ${ }^{d}$, J. Vander \\ Auwera $^{e}$ \\ ${ }^{a}$ Laboratoire Interdisciplinaire Carnot de Bourgogne, \\ UMR 5209 CNRS-Université de Bourgogne, \\ 9 avenue Alain Savary, B.P. 47870, F-21078 Dijon Cedex, France. \\ ${ }^{\boldsymbol{b}}$ Ligne AILES - Synchrotron SOLEIL, \\ L'Orme des Merisiers, F-91192, Gif-sur-Yvette, France. \\ ${ }^{c}$ Laboratoire de Photophysique Moléculaire, CNRS, \\ Bât. 210, Université Paris-Sud, 91405 Orsay Cedex, France \\ ${ }^{d}$ LADIR, UMR 7075 Université Pierre et Marie Curie-CNRS \\ Case 49, 4 place Jussieu, F-75252 Paris, France. \\ e Service de Chimie Quantique et Photophysique, C.P. 160/09, Université Libre de \\ Bruxelles, 50 avenue F. D. Roosevelt, B-1050 Brussels, Belgium.
}

\begin{abstract}
As a tetrahedral molecule, methane has no permanent dipole moment. Its spectrum, however, displays faint absorption lines in the $\mathrm{THz}$ region, due to centrifugal distorsion effects. This is important for planetary applications since this region is used to measure methane concentration in some planetary atmospheres, in particular on Titan. Up to now, all measurements relied either on some old low resolution infrared absorption spectra, or on high resolution Stark measurements for low $J$ values only. Even if these results have been reexamined recently [E. H. Wishnow, G. S. Orton, I. Ozier and H. P. Gush, J. Quant. Spectrosc. Radiat. Transfer 103, 102-117 (2007)], it seemed highly desirable to obtain much more precise laboratory data.

The high-intensity synchrotron radiation, combined with a $151.75 \pm 0.1 \mathrm{~m}$ optical path in a White cell and a Bruker IFS 125 HR FTIR spectrometer at the AILES beamline of SOLEIL, enabled us to record this very weak spectrum at high resolution for the first time. Spectra were obtained in the $50-500 \mathrm{~cm}^{-1}$ wavenumber range at $296 \mathrm{~K}$ and $9.91,20,50$ and 100 mbar with a resolution of $0.00074,0.00134,0.0034$ and $0.0067 \mathrm{~cm}^{-1}$ (FWHM of the sinc function),
\end{abstract}

\footnotetext{
This paper is dedicated to Dr. Larry Rothman on the occasion of his 70th birthday.

* To whom correspondence should be addressed.

E-mail: Vincent.Boudon@u-bourgogne.fr.

Fax : +33380395917
} 
respectively. The rotational clusters are fully resolved and the good signal-tonoise ratio has enabled precise measurements of transition intensities (92 cold band lines and 96 Dyad-Dyad hot band lines, with normal abundance intensities in the range $2.10^{-26}$ to $1.10^{-24} \mathrm{~cm}^{-1} /\left(\right.$ molecule. $\left.\mathrm{cm}^{-2}\right)$ ), yielding an accurate determination of the dipole moment derivatives. Such results should allow a better determination of $\mathrm{CH}_{4}$ concentration in planetary objects.

Keywords: Methane; Synchrotron radiation; Far infrared; Line intensities; Titan

\section{Introduction}

Besides being one of the major greenhouse gases on Earth [1, 2], methane $\left(\mathrm{CH}_{4}\right)$ is an important molecule for many planetary atmospheres, either in the Solar System (Mars [3], Jupiter [4, 5], Saturn [6] and its main satellite Titan [7, 8, 9, 10, 11], Uranus [12], Neptune [13] and its main satellite Triton [14], Pluto $[14,15])$ or also farther away, since it has now been identified in the gas envelop of at least two giant extrasolar planets (exoplanets HD 189733b [16] and HD 209458b [17]). In some cases, the presence of methane raises important questions about its origin (Mars [18, 19], Titan [20], exoplanets, ...) or leads to very interesting chemical processes (Titan [21]). Spectroscopy being the best (if not the sole) mean for studying such distant atmospheres, it is thus essential to have an accurate model of methane's absorption spectrum over a wide spectral range, from microwave to visible regions.

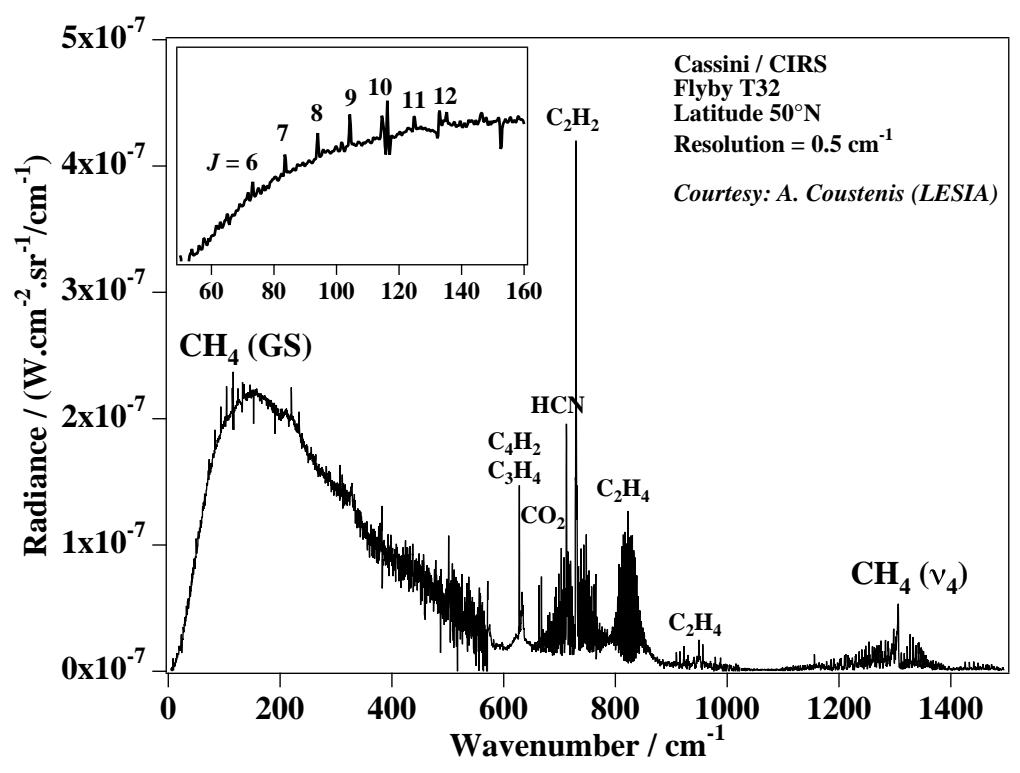

Figure 1: Example of a Cassini CIRS spectrum showing far infrared emission lines of methane. 
Far-infrared (THz) emission lines are for instance used to determine molecular abundances in the upper atmosphere (stratosphere) of several objects. This is especially the case for methane lines as observed on Titan (and Saturn) by CIRS (Composite InfraRed Spectrometer) aboard the Cassini spacecraft [22] (see Figure 1). Line positions in this region of the methane spectrum are already well-known, but it is crucial to also have a very good model for line intensities for such abundance measurements.

The $\mathrm{THz}$ spectrum of methane (which is in fact the $R$ branch of its pure rotational spectrum) is very weak, since it is induced by centrifugal distortion effects, as this highly-symmetrical molecule does not have a permanent dipole moment. It is thus difficult to study in the laboratory. Because of the importance of this spectrum for planetology, however, several attempts have been made previously to record it and to determine effective dipole moment parameters. A calculation of this induced dipole moment based on contact transformations was performed by Hilico et al. [23]. Previously, a low-resolution high-pressure spectrum was recorded at $113.5 \mathrm{~K}$ [24]. It has been reinvestigated recently [25], leading to a reevaluation of the intensities and an update included in the 2008 edition of the Hitran database [26]. Up to now, there existed only one partially resolved infrared absorption spectrum, recorded by McKellar in 1988 [27], but these results were never published. Finally, a high resolution and low pressure (100 mTorr) Stark measurement of the induced dipole moment has been reported [28], yielding a quite precise value however relying only on a limited number of low $J$ lines only.

It thus seemed highly desirable to obtain fully resolved high-resolution spectra in order to measure accurate intensities of individual spectral lines, instead of relying on low-resolution profiles of clusters of lines. This necessitates both a long-path spectroscopic cell and a very bright light source in the THz region, in order to maximize the signal-to-noise ratio. Consequently, the synchrotron radiation at the AILES beamline of the French synchrotron SOLEIL combined with a long path White cell is ideally suited for this purpose.

In this article, we firstly describe the experimental setup at SOLEIL and the recorded spectra. We then explain the method used to extract line intensities, the theoretical model used for the analysis and we finally discuss the results.

\section{Experimental details}

The absorption spectra of methane have been recorded in the $50-500 \mathrm{~cm}^{-1}$ spectral range on the far-infrared beamline AILES, located at the Synchrotron facility SOLEIL $[29,30]$. The intense far infrared continuum collected by the AILES beamline was focused on the entrance aperture of a high resolution IFS 125 Bruker interferometer, equipped for this experiment with a $6 \mu \mathrm{m}$ mylarSilicon composite beamsplitter and a $4.2 \mathrm{~K}$ bolometer fitted with a cold 600 $\mathrm{cm}^{-1}$ cut-off low pass filter. The scanner optical velocity was set to $2.53 \mathrm{~cm} / \mathrm{s}$.

A multipass cell (in a White type arrangement) was connected under vacuum to the interferometer and the optics (2.51 m base length) was adjusted to obtain $151.75(10) \mathrm{m}$ absorption pathlength. In order to limit the intense pure rotation 


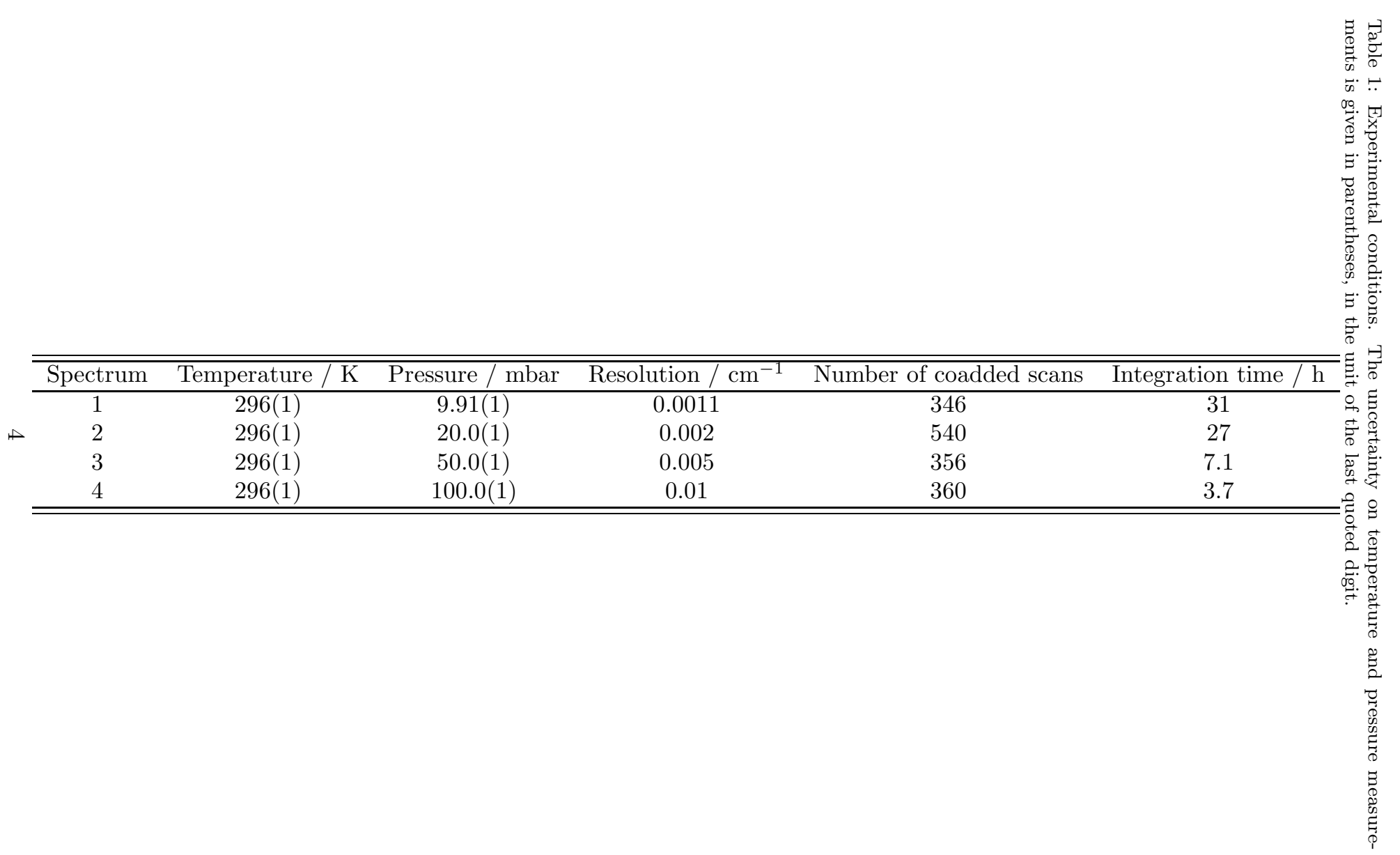


absorption lines of water the entire cell was pumped with a secondary pump while heated at about $70{ }^{\circ} \mathrm{C}$ for about 48 hours and cooled down for another 48 hours. The cell was isolated from the interferometer by $2 \mathrm{~cm}$ diameter, 50 $\mu \mathrm{m}$ thick polypropylene windows. During the acquisition of the spectra, the interferometer and the entire beamline were continuously evacuated by means of three magnetic-bearings turbopumps connected to the interferometer and the beamline, in order to limit the water line absorption outside the cell to negligible levels.

The experimental conditions are detailed in Table 1 . We recorded four spectra of pure methane at $23(1)^{\circ} \mathrm{C}$ and at $9.91 \mathrm{mbar}, 20 \mathrm{mbar}, 50 \mathrm{mbar}$, and 100 mbar (the optical path was identical for the four spectra). The pressures, measured with 10 and 100 mbar full-scale range temperature-controlled capacitance manometers, were constant during the acquisition of the four spectra. The resolutions were set to $0.00074,0.00134,0.0034$ and $0.0067 \mathrm{~cm}^{-1}$ (FWHM of the sinc function), respectively, using boxcar apodization.

Reference spectra were also recorded at different resolutions $(0.00074,0.00134$, 0.0034 and $0.0067 \mathrm{~cm}^{-1}$ ) in order to limit the baseline variations which may cause errors on the measured absolute intensities.

\section{Intensity measurements}

The individual line intensities were measured using a program developed in Brussels, which adjusts a synthetic spectrum to the observed spectrum of each line using a Levenberg-Marquardt least-squares fitting algorithm. The synthetic spectrum is calculated as the convolution of a monochromatic transmission spectrum with an instrument line shape function, which includes the effects of the finite maximum optical path difference and the finite entrance aperture in the interferometer [31]. The diameter $d$ of the focal point of the synchrotron beam at the entrance of the spectrometer was measured to be equal to about $0.8 \mathrm{~mm}$ at $1000 \mathrm{~cm}^{-1}$, decreasing proportionaly to the square root of the wavenumber, thus following the relation $d=0.8 \sqrt{1000 / \tilde{\nu}}$. The entrance aperture diameter was therefore set accordingly during the measurements. The profile of the lines in the monochromatic spectrum was modeled using a Voigt function [32] and the background was represented by a polynomial expansion, up to the third order. All the measurements performed involved the adjustment of the position, the intensity and the pressure self-broadening parameter of each line together with one to four background parameters. The Gaussian width of the Voigt profile was always held fixed to the value calculated for the Doppler broadening. The initial values of the line parameters required by the least squares fitting procedure were obtained from a peak finding procedure performed using the program "Wspectra" [33]. Altogether, we measured 167, 198, 109, and 133 absolute line intensities in the spectra recorded at sample pressures of 9.91,20, 50 and 100 mbar, respectively. Fewer measurements could be made in the $50 \mathrm{hPa}$ spectrum because of the somewhat worse signal-to-noise ratio. Intensities measured for the same line were averaged (each data being weighted by the inverse of the square of its estimated measurement uncertainty), rejecting data corresponding 
to lines assigned to at least two transitions of similar intensities, having observed intensities differing by more than a factor of 2 from the predicted one, and blended with water vapour lines. This reduced data set amounted to a total of 193 line intensities. They are listed in Table A.1 given in appendix. The uncertainty associated to each of these line intensities was estimated as the square root of the sum of the square of the measurement uncertainty and the square of the deviation of each measured intensity from the corresponding weighted average. The differences, calculated line by line, between the intensities measured at 9.91, 50 and $100 \mathrm{hPa}$ with those obtained at $20 \mathrm{hPa}$ (all being involved in the 193 weighted averages) have mean values and RMS deviations of $0.11 / 1.6,0.34 / 2.9$ and $0.61 / 4.810^{-26} \mathrm{~cm}^{-1} /\left(\right.$ molecule $\left.\mathrm{cm}^{-2}\right)$, respectively. These indicate that the measurements do not exhibit any systematic differences in the individual measurements from the different pressures. Figure 2 shows an example of the measurements.

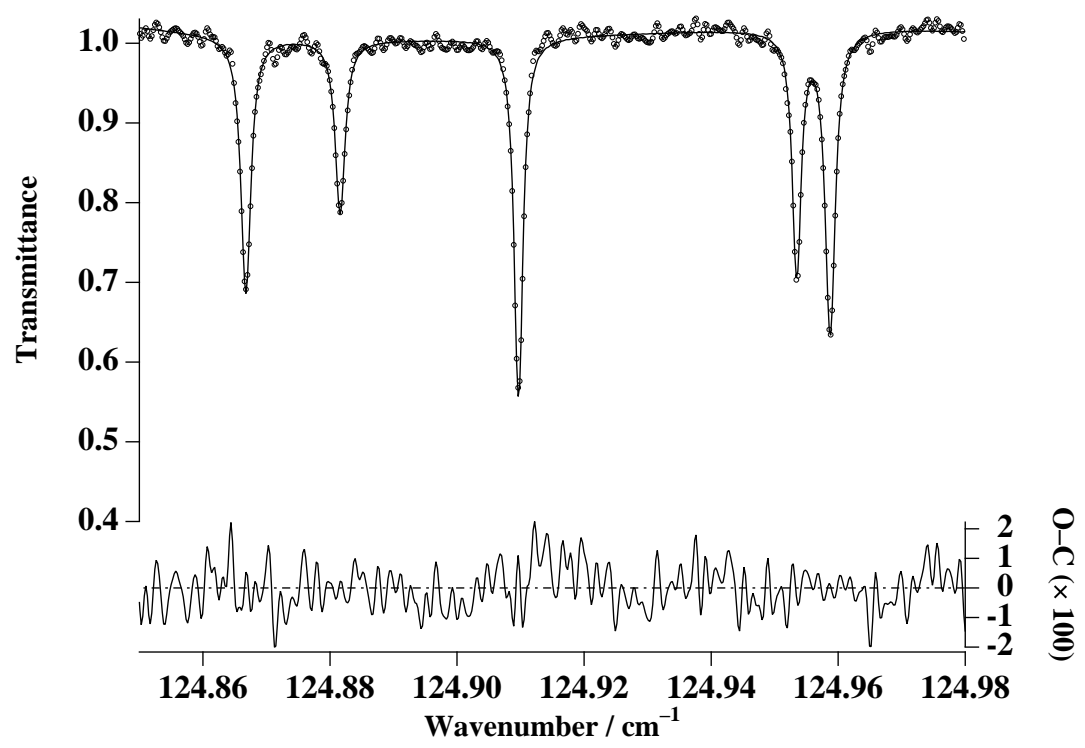

Figure 2: Part of the $R(11)$ region of the far infrared spectrum of ${ }^{12} \mathrm{CH}_{4}$ observed at 9.91 mbar (circles), and best fit calculated spectrum (solid line) and corresponding residuals (lower panel). Note that a rather wide range is shown here to illustrate the results of the fittings. The actual fits were carried on smaller regions, mainly because of the difficulties to reproduce correctly the residual channeling observed.

As indicated here above, the measurements involved the adjustment of the self-broadening parameter of each line. Indeed, it has never been measured for methane pure rotation lines and self-broadening parameters measured for one band do not necesseraly describe accurately the values for another band [34]. So, to avoid biasing the measured line intensities correlated to the line widths, we prefered to adjust the self-broadening parameter of each line instead 
of fixing it to an improper value. As the sample pressure was not high enough to allow precise determination of self-broadening parameters, we do not report these measurements. As a rough indication, the values obtained and their $J$ dependence are close to those observed for the strongest octad bands near 2.27 $\mu \mathrm{m}$ (see Fig. 5 of [34]).

\section{Theory}

The model we use here is based on the tensorial formalism developed in the Dijon group for methane and other spherical-top molecules [35, 36]. It is based on group theoretical and tensorial operator methods. We do not detail this formalism here, but we outline the elements used in the present study.

Two vibrational polyads of ${ }^{12} \mathrm{CH}_{4}$ are involved in this work: the Ground State (GS) and the $\nu_{2} / \nu_{4}$ bending Dyad. The spectra being recorded at room temperature, Dyad energy levels are significantly populated and thus we can observe both cold band lines (GS-GS rotational lines) and hot band lines (Dyad-Dyad rotational lines) in the $\mathrm{THz}$ region under investigation.

The effective Hamiltonian for the Ground State and for the Dyad are developed up to order 6 and the parameters are taken from the recent global fit of the first four methane polyads [37]. As we will see below, energy levels in the ground vibrational state of methane are already extremely well known (with a precision of $c a .50 \mathrm{kHz},[37])$ and thus the line positions in the $\mathrm{THz}$ region are perfectly well reproduced by the model. As a consequence, we did not make any attempt to re-fit line positions using the present data, but we rather focused entirely on line intensities.

As a spherical top, $\mathrm{CH}_{4}$ has no permanent dipole moment. But, when applying to the full dipole moment operator of the molecule the same contact transformation as the one used to isolate the different rovibrational polyads (see [35] for more details), some induced dipole moment terms appear even for pure rotational transitions. We consider here two effective dipole moment operators. The first one is the effective dipole moment for GS-GS transitions which expands as

$$
\mu^{\langle\mathrm{GS}-\mathrm{GS}\rangle}=\mu_{\{\mathrm{GS}-\mathrm{GS}\}}^{\langle\mathrm{GS}-\mathrm{GS}\rangle}=\mu_{0} R^{2\left(2, F_{2}\right)}+\ldots,
$$

up to order 1 . This term is due to centrifugal distorsion effects and depends on the $R^{2\left(2, F_{2}\right)}$ rotational operator (see [36] for definition). $\mu_{0}$ is a parameter to be determined from the experimental data. It should be noticed that the $\mu_{D}$ parameter used in [25] is related to $\mu_{0}$ by

$$
\mu_{D}=\sqrt{8} \mu_{0}
$$

The second effective dipole moment operator we use is the one for Dyad-Dyad transitions,

$$
\begin{aligned}
\mu^{\langle\text {Dyad-Dyad }\rangle} & =\mu_{\{\text {GS }- \text { GS }\}}^{\langle\text {Dyad }- \text { Dyad }\rangle}+\mu_{\left\{\nu_{2}-\nu_{4}\right\}}^{\langle\text {Dyad }- \text { Dyad }\rangle}+\mu_{\left\{\nu_{4}-\nu_{4}\right\}}^{\langle\text {Dyad }\}} \\
& =\mu_{0} R^{2\left(2, F_{2}\right)}+\mu_{2,4} V_{2,4}^{E F_{2}\left(F_{2}\right)}+\mu_{4,4}^{F_{2} F_{2}\left(F_{2}\right)} V_{4,4}^{F_{2} F_{2}\left(F_{2}\right)}+\ldots
\end{aligned}
$$


As explained in [35, 36], the effective dipole moment for hot bands is based on an extrapolation scheme: in the present case, for instance, the Dyad-Dyad effective dipole moment contains the $\mu_{\{\mathrm{GS}-\mathrm{GS}\}}^{\langle\mathrm{Dyad}-\mathrm{Dyad}\rangle}$ term that is formally identical to the GS-GS effective dipole moment, $\mu_{\{\mathrm{GS}-\mathrm{GS}\}}^{\langle\mathrm{GS}-\mathrm{GS}\rangle}$. This allows, in principle, to perform a simultaneous analysis of GS-GS and Dyad-Dyad intensities.

The last two terms in (3) are dipole moment derivatives specific to Dyad-Dyad transitions. $V_{2,4}^{E F_{2}\left(F_{2}\right)}$ and $V_{4,4}^{F_{2} F_{2}\left(F_{2}\right)}$ are vibrational operators relative to $\nu_{2}-\nu_{4}$ and $\nu_{4}-\nu_{4}$ transitions, respectively (see [35] for details about the tensorial construction of vibrational operators for tetrahedral molecules), while $\mu_{2,4}$ and $\mu_{4,4}$ are the corresponding parameters to be determined. Figure 3 summarizes schematically the lowest vibrational levels of methane and the effective dipole moment operators implied for rotational transitions. The $\mu_{4,4}$ parameter is related to the $\left(\mu_{z}\right)_{\text {eff }}$ parameter of Mills et al. [38] through the relation [39]

$$
\mu_{4,4}=-\sqrt{6}\left(\mu_{z}\right)_{\mathrm{eff}} .
$$
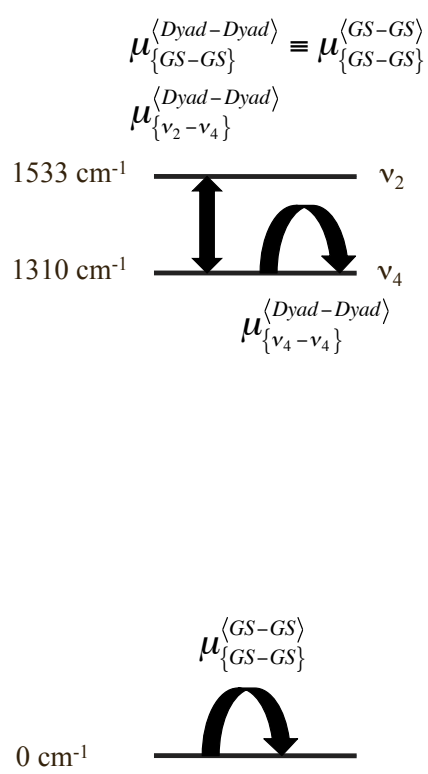

Figure 3: Schema of the lowest vibrational levels of $\mathrm{CH}_{4}$ with the effective Hamiltonian operators involved in $\mathrm{THz}$ rotational transitions.

\section{Analysis and results}

We first performed a preliminary simulation using the existing parameters: effective Hamiltonian parameters from [37] and effective dipole moment param- 
eters from [25]. As it is shown on Fig. 4, the result is already very convincing. It should be noticed that hot band lines have significant intensities. Water lines are also present but, fortunately, they generally do not overlap too much with methane lines. Figure 5 shows another comparison for different pressures.

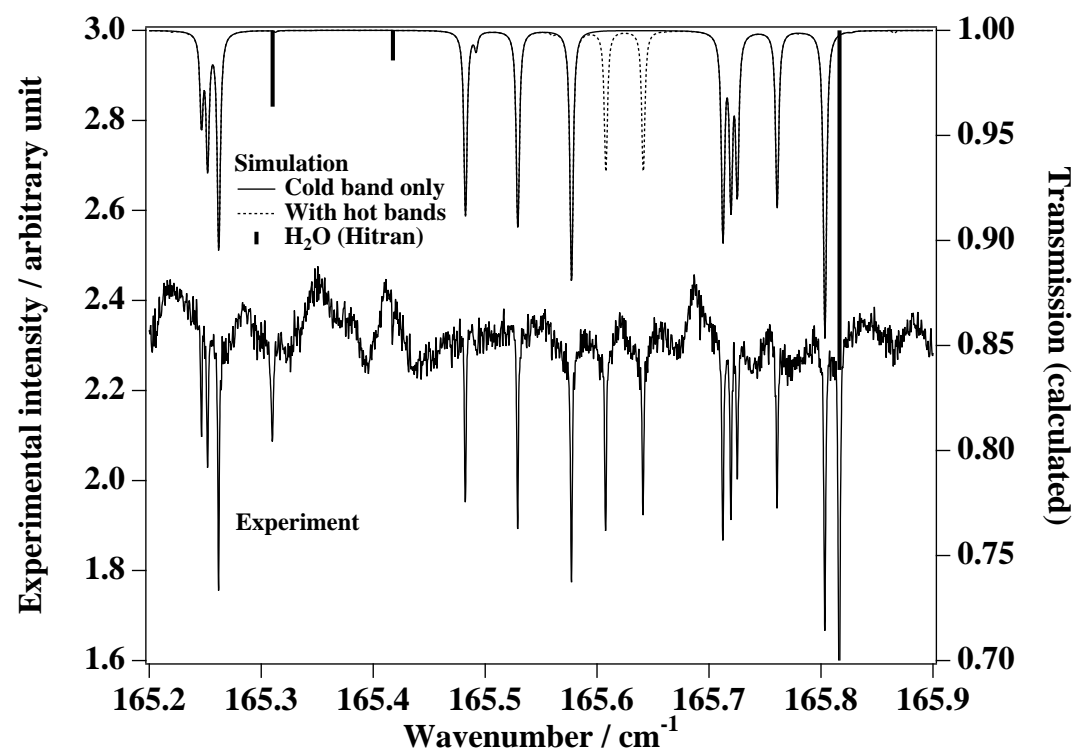

Figure 4: Example of comparison between the experimental spectrum and the simulation: the $R(15)$ region. Two simulations are presented (top): one with cold band lines only (continuous line) and one including hot band lines (dashed line). Three $\mathrm{H}_{2} \mathrm{O}$ lines taken from the Hitran database are indicated by vertical sticks.

Line assignments were thus straightforward. They are also given in Table A.1. The lower state rotational quantum number range for assigned lines is $7 \leq J \leq 18$ for the cold band and $2 \leq J \leq 14$ for the hot bands. We could then perform three different fits of the effective dipole moment parameters, using the experimental intensities extracted from the spectra as explained in Section 3. As measurements were performed for natural abundance methane, we multiplied the calculated lines by the the 0.988274 isotopic factor [26]. All lines for which the relative intensity deviation exceeded $40 \%$ were automatically rejected by the fitting program. Examination of the 5 line intensities rejected showed that they all correspond to quite weak (compared to the signal to noise ratio) and/or blended lines. The results are presented in Table 2 and discussed below.

Fit 1 includes only cold band line intensities (i.e. GS-GS transitions). Although the root mean square deviation $d_{\text {RMS }}$ is somewhat high $(c a .9 .3$ $\%$ ), we get a $\mu_{0}\left(\right.$ or $\left.\mu_{D}\right)$ value with a good precision, significantly better than in the previous study [25]. The $\mu_{D}$ value appears to be quite close to the calculated value from Hilico et al. [23] and thus lower than that of 


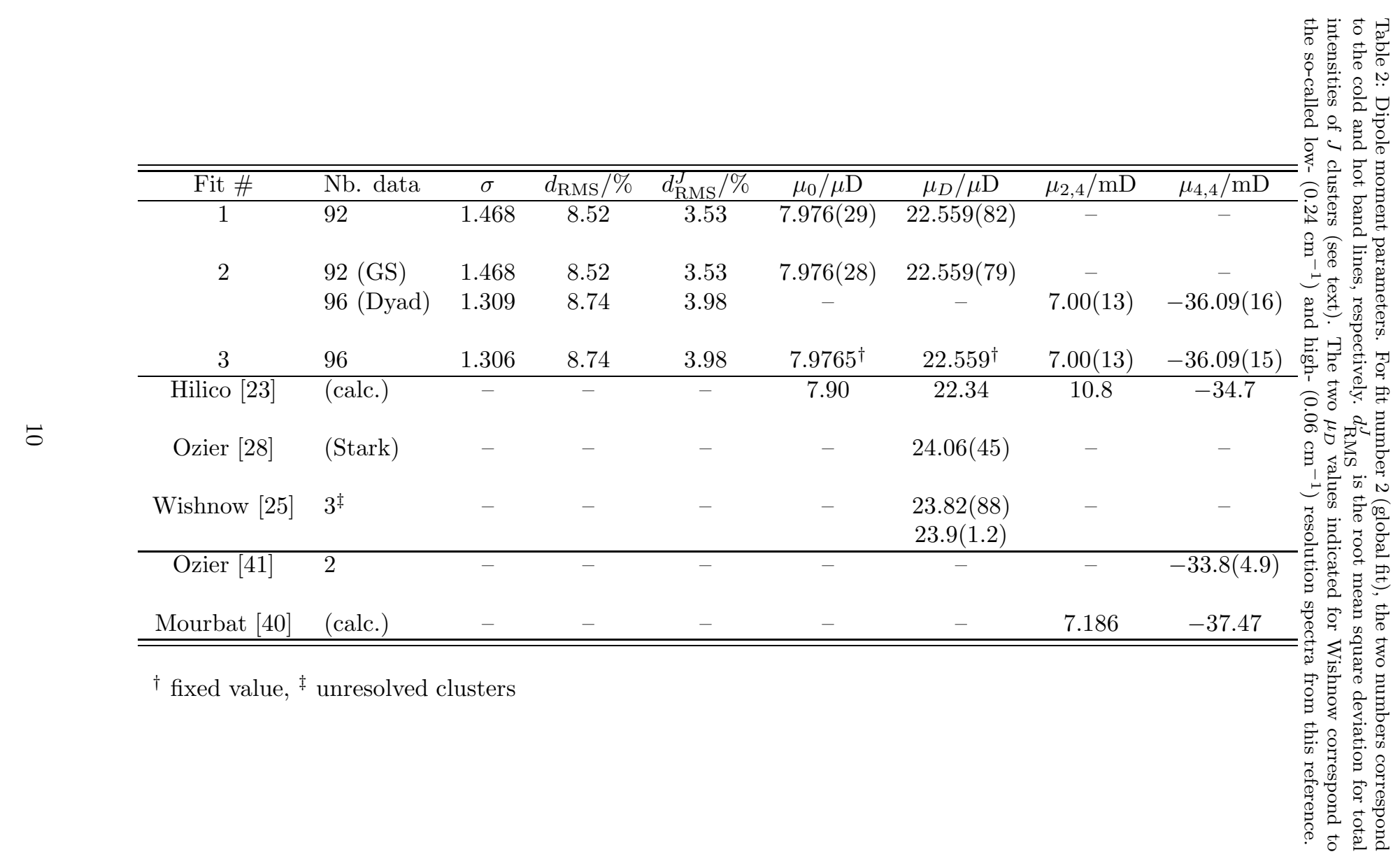




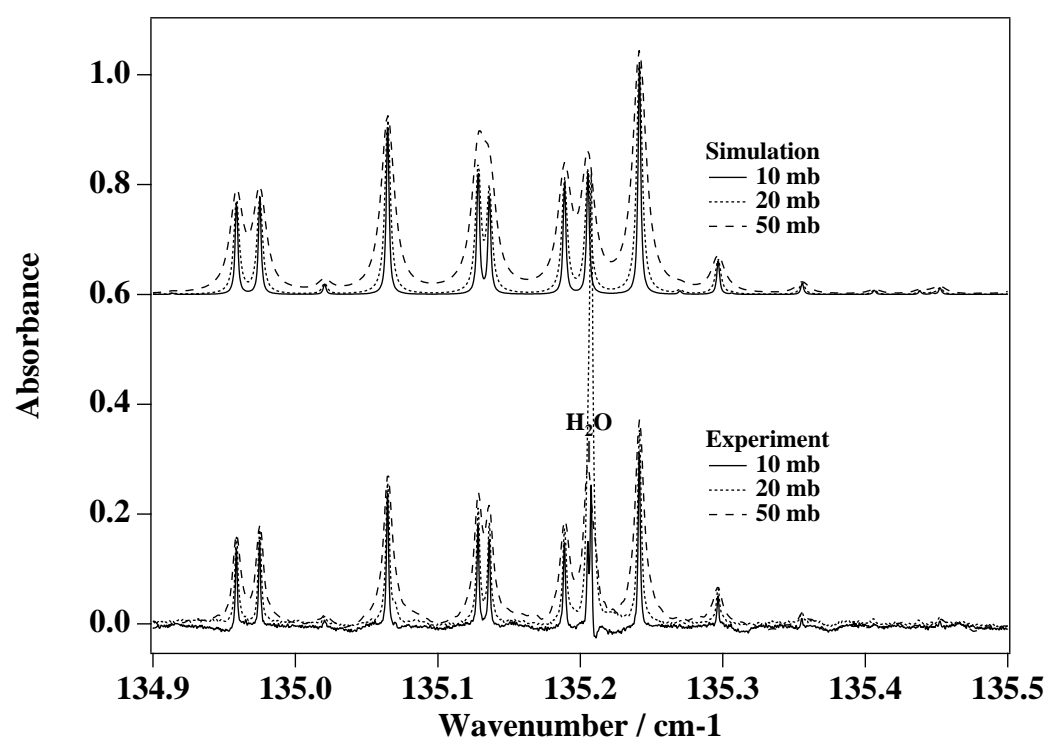

Figure 5: Examples of comparison between experimental spectra at different pressures and the corresponding simulations, in the $R(12)$ region. The most prominent line in the experimental spectra is due to $\mathrm{H}_{2} \mathrm{O}$, as indicated.

Wishnow et al. [25], obtained from low-resolution high-pressure spectra. The value from Stark measurements [28], also quite precise, is somewhat higher. This can reflect an underestimated experimental uncertainty on the Stark value. Alternatively, it might arise from the fact that the Stark value characterizes $\Delta J$ matrix elements for $\mathrm{J}=2$ only, while the present value characterizes $\Delta J= \pm 1$ matrix elements for $J$ values in the 7 to 18 range.

Fit 2 includes both cold and hot band line intensities (i.e. GS-GS and Dyad -Dyad transitions) in order to determine simultaneously $\mu_{0}, \mu_{2,4}$ and $\mu_{4,4}$. Figure 6 displays the fit residuals in this case. They are also included in Table A.1. This second fit is fully consistent with the previous one, in agreement with the vibrational extrapolation for the effective dipole moment (see previous section). It should be noticed, however, that the GS-GS and Dyad-Dyad intensity datasets are virtually independent; a careful analysis of the fit results shows that $\mu_{0}$ is determined by GS-GS data only, while the other two parameters are fully determined by Dyad-Dyad data.

Fit 3 is similar to Fit 2, but this time with $\mu_{0}$ fixed to the value from Fit 

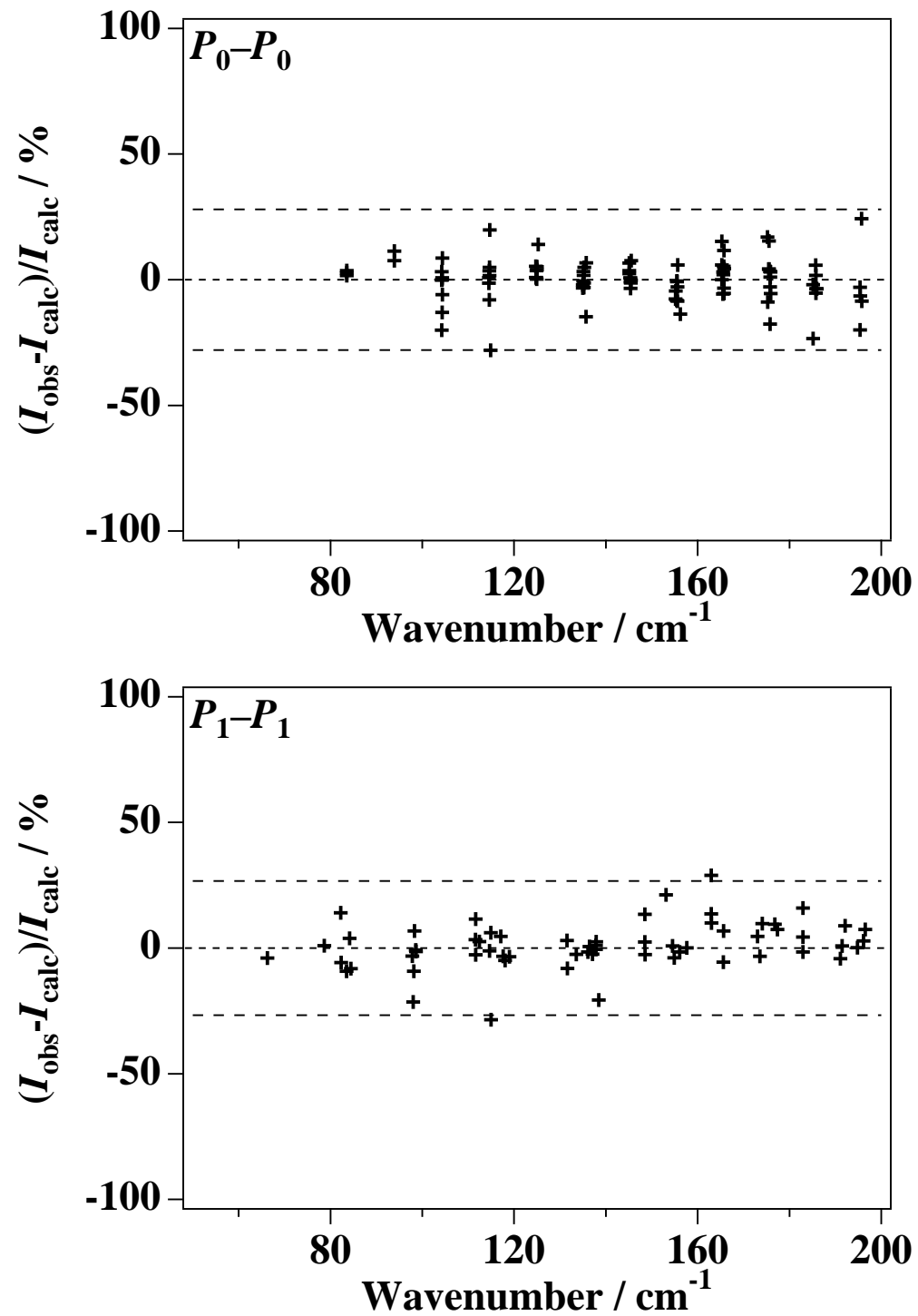

Figure 6: Fit residuals for line intensities for the cold (top) and hot (bottom) band lines in the case of the global fit. The upper and lower dashed lines display the $\pm 3 d_{\mathrm{RMS}}$ interval. 

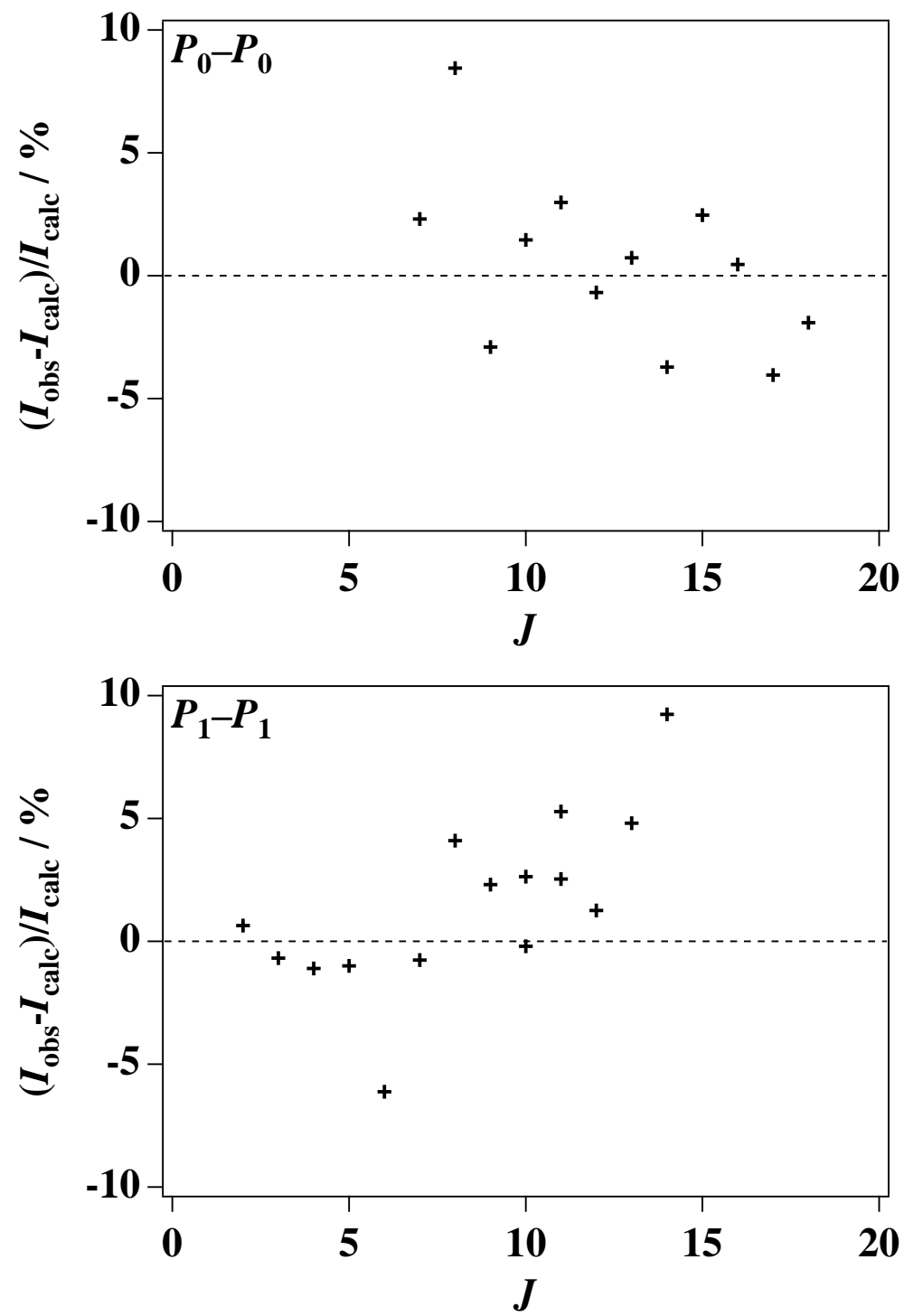

Figure 7: Fit residuals for total intensities of each $R(J)$ cluster in the case of the global fit. 
1. This gives $\mu_{2,4}$ and $\mu_{4,4}$ identical to those from Fit 2 (with the same residuals as in Figure 6), confirming the full consistency of the results.

While the root mean square deviation calculated with all individual line intensities is close to $9 \%$, it appears that the total intensity of each $R(J)$ cluster of lines compares even better to the experiment. Figure 7 shows the fit resituals for intensity sums for each $J$ value. The root mean square deviation calculated for these intensity sums, $d_{\mathrm{RMS}}^{J}$, is lower than $4 \%$ for both cold and hot band lines (see Table 2). Figure 8 shows the calculated rovibrational energy levels in the Ground State and the Dyad with the levels involved in the observed transitions marked in black. This gives an idea of how the present spectra sample the energy levels.
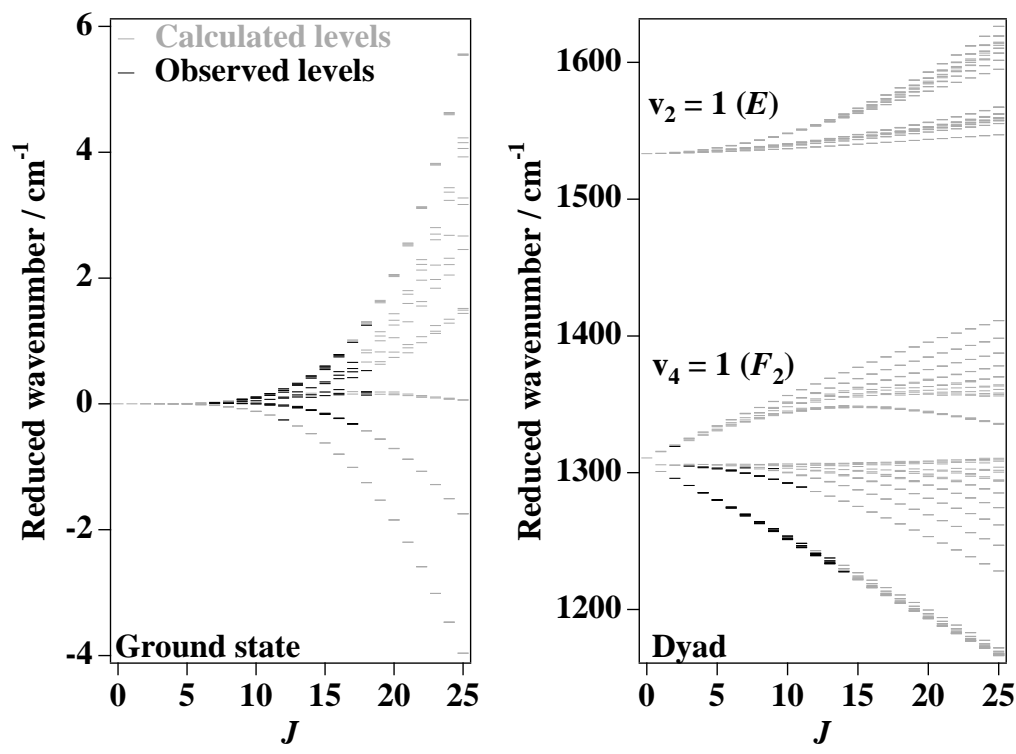

Figure 8: Reduced energy levels showing those reached by observed transitions (in black) corresponding to cold (left) and hot band lines (right).

The main outcome of this work is that we can recommend for $\mu_{D}$ the value

$$
\mu_{D}=22.559(79) \mu \mathrm{D}
$$

and for the vibrational parameters for the hot bands the values

$$
\mu_{2,4}=7.00(13) \mathrm{mD}, \quad \mu_{4,4}=-36.09(16) \mathrm{mD} .
$$

The numbers given between parentheses are the standard deviation of the fit, in the units of the last quoted digit. To estimate the effect of the uncertainty on the temperature on the determined value of $\mu_{D}$, Fit 1 was also done assuming that the line intensities had been measured at $295 \mathrm{~K}$ (instead of $296 \mathrm{~K}$ ). The 
obtained value and corresponding uncertainty, $\mu_{D}=22.624(82) \mu \mathrm{D}$, show that the variation is within the given standard deviation.

The $\mu_{4,4}$ value we find here is quite consistent with previous theoretical $[23,40]$ and experimental values [41]. The signs are taken here identical as in the theoretical work of Ref. [23].

It should also be noticed that the hot band lines used in Fit 2 and Fit 3 contain only one $\nu_{2}-\nu_{4}$ line. This means that only one upper level is assigned to a $v_{2}=1$ level. But it should be kept in mind that, due to the Coriolis coupling between the $v_{2}=1$ and $v_{4}=1$ levels, all rovibrational levels are mixed and so-called $v_{4}=1$ levels contain a contribution from $v_{2}=1$ levels. There is thus an intensity sharing between both hot bands and this allows a correct determination of $\mu_{2,4}$, although this one should probably be considered with some care.

Figure 9 summarizes the situation for a small portion of the spectrum, showing again that our value is close to the the value of Hilico et al. [23] and lower than that of Wishnow et al. [25]. The latter reference recommended to multiply the $\mathrm{THz}$ methane intensities available in the Hitran 2004 database [42], based on the calculated values from Hilico et al. [23], by a factor 1.154. This was done in the Hitran 2008 edition [26]. We recommend here the factor 1.019 obtained both from Fit 1 and Fit 2.

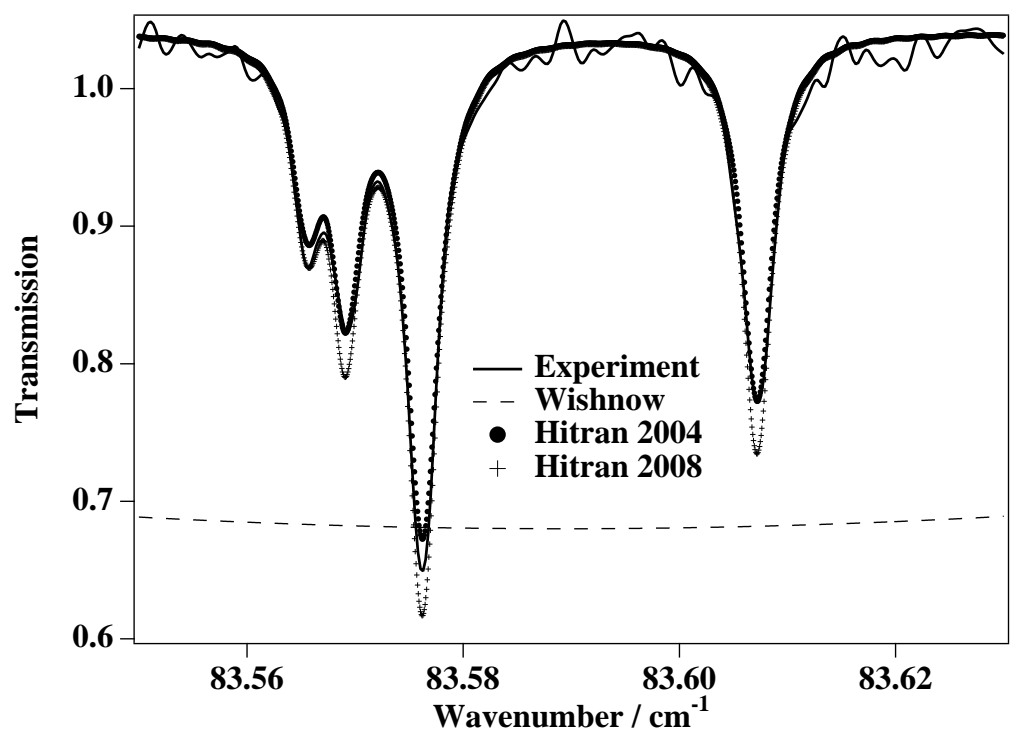

Figure 9: Comparison of the present measurements with the Wishnow et al. low resolution spectrum and with simulations using the Hitran 2004 and Hitran 2008 databases. 


\section{Conclusion}

We presented here the first high-resolution spectra of methane ever recorded in the $\mathrm{THz}$ region with synchrotron radiation. These high quality spectra allowed to measure line intensities and to obtain precise effective dipole moment parameters for pure rotation transitions in the ground and $v_{4}=1$ states. The intensity information also obtained for the $\nu_{2}-\nu_{4}$ band is probably rather approximate as it is mainly obtained through intensity sharing due to the Coriolis coupling between lines involving the $v_{2}=1$ and $v_{4}=1$ states. The measurements also led to the determination of self-broadening parameters, found to rougly agree with those observed for the strongest bands near $2.27 \mu \mathrm{m}$. They are however not reported because the sample pressure was not high enough to allow their precise determination.

Despite the large improvements in signal-to-noise ratio provided by synchrotron radiation, the root mean square deviation obtained here remains large. Further improvements in the retrieved information could result from higher signal-to-noise ratios recently achieved at the AILES beamline [30] or the use of "multispectrum" line parameters retrieval techniques [43].

We hope that the present results will help improving the interpretation of planetary atmosphere spectra, providing more precise determinations of methane concentrations in such environments. Along this line, a further improvement of the spectroscopic information available for the $\mathrm{THz}$ spectrum of methane would involve the study of $\mathrm{N}_{2}$ collisional broadening effects.

\section{Acknowledgements}

This work is part of the French ANR project " $\mathrm{CH}_{4}$ Titan" (ref: BLAN082_321467). VB also acknowledges the support of the "Pôle de Sciences Planétaires" of Bourgogne Franche-Comté and the "SpecMo GdR" number 3152 of the CNRS. JVDA acknowledges financial support from the Fonds de la Recherche Scientifique (FRS-FNRS, Belgium, contracts FRFC and IISN), and the Action de Recherches Concertées of the Communauté française de Belgique. The AILES group at SOLEIL wishes to thank Mathieu Rouzires and Didier Balcon for their help. 


\section{Appendix A. Line list}

Table A.1 : Intensities [in $\mathrm{cm}^{-1} /\left(\right.$ molecule $\left.\mathrm{cm}^{-2}\right)$ at $\left.296 \mathrm{~K}\right]$ measured for pure rotational lines of ${ }^{12} \mathrm{CH}_{4}$, in natural abundance. This table is also given in ASCII form as supplementary material to this paper.

\section{Table headings :}

\begin{tabular}{|c|c|}
\hline  & $\begin{array}{l}\text { number of intensities averaged to yield the observed intensity given under } \\
\text { heading "Intensity"; }\end{array}$ \\
\hline Posi & sition, in $\mathrm{cm}^{-1}$ \\
\hline & dine intensities; \\
\hline Unc & $\begin{array}{l}\text { ncertainty, estimated as the square root of the sum of the square of } \\
\text { ne measurement uncertainty and the square of the deviation of each } \\
\text { eeasured intensity from "Intensity"; }\end{array}$ \\
\hline $\mathrm{U} / \%$ & sity"; \\
\hline $\mathrm{O}-\mathrm{C} / \mathrm{S}$ & $\begin{array}{l}\text { "Intensity" minus the intensity calculated a } \\
5 \text { ), expressed as a percentage of the calcula }\end{array}$ \\
\hline E" & \\
\hline Bd & $\begin{array}{l}\mathrm{CB}=\text { transition within the ground state, } \mathrm{H} 1=\text { transition within } v_{4}=1, \\
\mathrm{H} 2=\nu_{2}-\nu_{4} \text { band; }\end{array}$ \\
\hline & \\
\hline $\mathbf{J}$, & $\begin{array}{l}\text { total angular momentum quantum number, symmetry ( } T_{d} \text { group irreps), } \\
\text { multiplicity index and main component for the projection on the initial } \\
\text { basis, for the lower (") and upper states. }\end{array}$ \\
\hline
\end{tabular}


Table A.1: Intensities [in $\mathrm{cm}^{-1} /\left(\right.$ molecule $\left.\mathrm{cm}^{-2}\right)$ at $296 \mathrm{~K}$ ] measured for pure rotational lines of ${ }^{12} \mathrm{CH}_{4}$, in natural abundance.

\begin{tabular}{|c|c|c|c|c|c|c|c|c|c|c|c|c|c|c|c|c|c|c|}
\hline$\overline{\#}$ & Position & Intensity & Unc. & $\overline{\mathrm{U} / \%}$ & $\mathrm{O}-\mathrm{C} / \%$ & $\overline{E "}$ & $\overline{\mathrm{Bd}}$ & $\overline{\mathrm{Br}}$ & J" & C" & n" & & \#vib" & $\overline{\mathrm{J}}$ & $\overline{\mathrm{C}}$ & $\overline{\mathrm{n}}$ & & \#vib \\
\hline 1 & 59.08187 & $1.372 \mathrm{E}-25$ & $9.5 \mathrm{E}-27$ & 6.9 & 69. & 1327.30839 & $\mathrm{H} 1$ & $\mathrm{R}$ & 2 & $\mathrm{~F} 2$ & 1 & 2 & $100 \%$ & 3 & F1 & 3 & 2 & $99 \%$ \\
\hline 1 & 66.23860 & $7.277 \mathrm{E}-26$ & $4.9 \mathrm{E}-27$ & 6.7 & -4.0 & 1367.73340 & $\mathrm{H} 1$ & $\mathrm{R}$ & 3 & $\mathrm{~F} 2$ & 1 & 2 & $99 \%$ & 4 & $\mathrm{~F} 1$ & 3 & 2 & $100 \%$ \\
\hline 1 & 77.49102 & $9.177 \mathrm{E}-26$ & $1.5 \mathrm{E}-26$ & 17. & 65. & 1596.72572 & H1 & $\mathrm{R}$ & 7 & A1 & 2 & 2 & $99 \%$ & 8 & A2 & 1 & 2 & $96 \%$ \\
\hline 3 & 78.65308 & $1.525 \mathrm{E}-25$ & $4.4 \mathrm{E}-26$ & 29. & 1.0 & 1353.52728 & $\mathrm{H} 1$ & $\mathrm{R}$ & 3 & $\mathrm{~F} 1$ & 1 & 2 & $100 \%$ & 4 & $\mathrm{~F} 2$ & 3 & 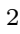 & $99 \%$ \\
\hline 3 & 82.21987 & $2.368 \mathrm{E}-25$ & $1.8 \mathrm{E}-26$ & 7.8 & 14. & 1408.48479 & $\mathrm{H} 1$ & $\mathrm{R}$ & 4 & $\mathrm{~A} 2$ & 1 & 2 & $99 \%$ & 5 & A1 & 1 & 2 & $99 \%$ \\
\hline 2 & 82.31512 & $8.136 \mathrm{E}-26$ & $2.1 \mathrm{E}-26$ & 26. & -5.7 & 1409.00661 & $\mathrm{H} 1$ & $\mathrm{R}$ & 4 & $\mathrm{~F} 2$ & 2 & 2 & $99 \%$ & 5 & F1 & 4 & 2 & $100 \%$ \\
\hline 1 & 83.52005 & $3.329 \mathrm{E}-26$ & $2.5 \mathrm{E}-27$ & 7.5 & -9.2 & 1641.04784 & $\mathrm{H} 1$ & $\mathrm{Q}$ & 8 & $\mathrm{~F} 1$ & 2 & 2 & $99 \%$ & 8 & $\mathrm{~F} 2$ & 7 & 2 & $99 \%$ \\
\hline 2 & 83.56549 & $7.909 \mathrm{E}-26$ & $1.4 \mathrm{E}-26$ & 18. & 2.7 & 293.16993 & $\mathrm{CB}$ & $\mathrm{R}$ & 7 & $\mathrm{E}$ & 1 & 1 & $100 \%$ & 8 & $\mathrm{E}$ & 1 & 1 & $100 \%$ \\
\hline 2 & 83.56913 & $1.366 \mathrm{E}-25$ & $4.7 \mathrm{E}-26$ & 34. & 3.6 & 293.16437 & $\mathrm{CB}$ & $\mathrm{R}$ & 7 & $\mathrm{~F} 2$ & 2 & 1 & $100 \%$ & 8 & F1 & 1 & 1 & $100 \%$ \\
\hline 2 & 83.57622 & $2.940 \mathrm{E}-25$ & $9.8 \mathrm{E}-27$ & 3.3 & 1.7 & 293.15400 & $\mathrm{CB}$ & $\mathrm{R}$ & 7 & $\mathrm{~A} 2$ & 1 & 1 & $100 \%$ & 8 & A1 & 1 & 1 & $100 \%$ \\
\hline 1 & 84.14751 & $5.149 \mathrm{E}-26$ & $6.2 \mathrm{E}-27$ & 12. & 3.9 & 1437.32117 & $\mathrm{H} 1$ & $\mathrm{R}$ & 5 & $\mathrm{~F} 2$ & 1 & 2 & $100 \%$ & 6 & F1 & 2 & 2 & $98 \%$ \\
\hline 2 & 84.47025 & $1.132 \mathrm{E}-25$ & $2.0 \mathrm{E}-26$ & 18. & -8.2 & 1437.49370 & $\mathrm{H} 1$ & $\mathrm{R}$ & 5 & $\mathrm{~A} 2$ & 1 & 2 & $100 \%$ & 6 & A1 & 1 & 2 & $98 \%$ \\
\hline 3 & 93.91555 & $1.851 \mathrm{E}-25$ & $1.3 \mathrm{E}-26$ & 6.9 & 11. & 376.80455 & $\mathrm{CB}$ & $\mathrm{R}$ & 8 & $\mathrm{~F} 1$ & 2 & 1 & $100 \%$ & 9 & $\mathrm{~F} 2$ & 1 & 1 & $100 \%$ \\
\hline 3 & 93.93107 & $2.259 \mathrm{E}-25$ & $3.6 \mathrm{E}-26$ & 16. & 7.6 & 376.78565 & $\mathrm{CB}$ & $\mathrm{R}$ & 8 & $\mathrm{~F} 2$ & 1 & 1 & $100 \%$ & 9 & F1 & 1 & 1 & $100 \%$ \\
\hline 1 & 93.95225 & $4.521 \mathrm{E}-26$ & $5.1 \mathrm{E}-27$ & 11. & 62. & 1773.78112 & $\mathrm{H} 1$ & $\mathrm{R}$ & 9 & $\mathrm{~A} 2$ & 2 & 2 & $98 \%$ & 10 & A1 & 2 & 2 & $94 \%$ \\
\hline 4 & 97.81532 & $4.147 \mathrm{E}-25$ & $7.9 \mathrm{E}-26$ & 19. & -3.2 & 1389.95202 & $\mathrm{H} 1$ & $\mathrm{R}$ & 4 & $\mathrm{~A} 1$ & 1 & 2 & $100 \%$ & 5 & A2 & 2 & 2 & $98 \%$ \\
\hline 1 & 98.02992 & $5.120 \mathrm{E}-26$ & $5.7 \mathrm{E}-27$ & 11. & -21 & 1494.72267 & $\mathrm{H} 1$ & $\mathrm{R}$ & 6 & $\mathrm{~F} 1$ & 1 & 2 & $99 \%$ & 7 & $\mathrm{~F} 2$ & 2 & 2 & $97 \%$ \\
\hline 2 & 98.07789 & $4.374 \mathrm{E}-26$ & $2.7 \mathrm{E}-26$ & 62. & -43 & 1494.94792 & $\mathrm{H} 1$ & $\mathrm{R}$ & 6 & $\mathrm{~F} 2$ & 2 & 2 & $100 \%$ & 7 & F1 & 3 & 2 & $97 \%$ \\
\hline 2 & 98.17557 & $2.003 \mathrm{E}-25$ & $3.3 \mathrm{E}-26$ & 16. & -9.2 & 1390.13327 & $\mathrm{H} 1$ & $\mathrm{R}$ & 4 & $\mathrm{~F} 1$ & 1 & 2 & $100 \%$ & 5 & $\mathrm{~F} 2$ & 4 & 2 & $98 \%$ \\
\hline 2 & 98.30354 & $1.295 \mathrm{E}-25$ & $1.2 \mathrm{E}-26$ & 9.3 & 6.8 & 1460.50595 & $\mathrm{H} 1$ & $\mathrm{R}$ & 5 & $\mathrm{~F} 1$ & 2 & 2 & $99 \%$ & 6 & $\mathrm{~F} 2$ & 5 & 2 & $100 \%$ \\
\hline 1 & 98.58852 & $1.256 \mathrm{E}-25$ & $3.0 \mathrm{E}-27$ & 2.4 & -0.8 & 1459.91150 & $\mathrm{H} 1$ & $\mathrm{R}$ & 5 & $\mathrm{~F} 2$ & 2 & 2 & $98 \%$ & 6 & $\mathrm{~F} 1$ & 5 & & $99 \%$ \\
\hline 2 & 98.62756 & $1.827 \mathrm{E}-25$ & $1.6 \mathrm{E}-26$ & 9.0 & -1.4 & 1390.28526 & $\mathrm{H} 1$ & $\mathrm{R}$ & 4 & $\mathrm{~F} 2$ & 1 & 2 & $100 \%$ & 5 & $\mathrm{~F} 1$ & 3 & 2 & $99 \%$ \\
\hline 4 & 104.22470 & $3.375 \mathrm{E}-25$ & $4.2 \mathrm{E}-26$ & 13. & 3.2 & 470.83073 & $\mathrm{CB}$ & $\mathrm{R}$ & 9 & $\mathrm{~A} 1$ & 1 & 1 & $100 \%$ & 10 & A2 & 1 & 1 & $100 \%$ \\
\hline 2 & 104.24737 & $2.187 \mathrm{E}-25$ & $8.6 \mathrm{E}-27$ & 3.9 & -0.2 & 470.80505 & $\mathrm{CB}$ & $\mathrm{R}$ & 9 & $\mathrm{~F} 1$ & 2 & 1 & $100 \%$ & 10 & $\mathrm{~F} 2$ & 1 & 1 & $100 \%$ \\
\hline 2 & 104.25229 & $1.326 \mathrm{E}-25$ & $4.3 \mathrm{E}-26$ & 33. & -20 . & 470.79874 & $\mathrm{CB}$ & $\mathrm{R}$ & 9 & $\mathrm{E}$ & 1 & 1 & $100 \%$ & 10 & $\mathrm{E}$ & 1 & 1 & $100 \%$ \\
\hline 2 & 104.31507 & $2.432 \mathrm{E}-25$ & $1.4 \mathrm{E}-26$ & 5.8 & -13 & 470.85477 & $\mathrm{CB}$ & $\mathrm{R}$ & 9 & $\mathrm{~F} 1$ & 3 & 1 & $100 \%$ & 10 & $\mathrm{~F} 2$ & 2 & 1 & $100 \%$ \\
\hline 2 & 104.31924 & $2.579 \mathrm{E}-25$ & $2.9 \mathrm{E}-26$ & 11. & 0.1 & 470.86482 & $\mathrm{CB}$ & $\mathrm{R}$ & 9 & $\mathrm{~F} 2$ & 2 & 1 & $100 \%$ & 10 & $\mathrm{~F} 1$ & 1 & 1 & $100 \%$ \\
\hline 4 & 104.35000 & $5.639 \mathrm{E}-25$ & $9.1 \mathrm{E}-26$ & 16. & 0.7 & 470.87268 & $\mathrm{CB}$ & $\mathrm{R}$ & 9 & $\mathrm{~A} 2$ & 1 & 1 & $100 \%$ & 10 & A1 & 1 & 1 & $100 \%$ \\
\hline 2 & 104.36479 & $5.884 \mathrm{E}-26$ & $1.4 \mathrm{E}-26$ & 23. & 8.5 & 470.80505 & $\mathrm{CB}$ & $\mathrm{R}$ & 9 & $\mathrm{~F} 1$ & 2 & 1 & $100 \%$ & 10 & $\mathrm{~F} 2$ & 2 & 1 & $100 \%$ \\
\hline 1 & 104.39473 & $5.951 \mathrm{E}-26$ & $6.1 \mathrm{E}-27$ & 10. & -6.0 & 470.86482 & $\mathrm{CB}$ & $\mathrm{R}$ & 9 & $\mathrm{~F} 2$ & 2 & 1 & $100 \%$ & 10 & $\mathrm{~F} 1$ & 2 & 1 & $100 \%$ \\
\hline 2 & 111.60251 & $8.491 \mathrm{E}-26$ & $1.7 \mathrm{E}-26$ & 20. & 3.4 & 1562.78797 & $\mathrm{H} 1$ & $\mathrm{R}$ & 7 & $\mathrm{~F} 1$ & 2 & 2 & $99 \%$ & 8 & $\mathrm{~F} 2$ & 3 & & $96 \%$ \\
\hline 2 & 111.62766 & $6.644 \mathrm{E}-26$ & $1.7 \mathrm{E}-26$ & 25 . & 12. & 1562.85866 & $\mathrm{H} 1$ & $\mathrm{R}$ & 7 & $\mathrm{E}$ & 1 & 2 & $99 \%$ & 8 & $\mathrm{E}$ & 2 & 2 & $96 \%$ \\
\hline 2 & 111.64262 & $1.224 \mathrm{E}-25$ & $2.5 \mathrm{E}-26$ & 21. & -2.7 & 1562.57412 & $\mathrm{H} 1$ & $\mathrm{R}$ & 7 & $\mathrm{~A} 1$ & 1 & 2 & $99 \%$ & 8 & $\mathrm{~A} 2$ & 1 & 2 & $96 \%$ \\
\hline 1 & 112.46121 & $4.093 \mathrm{E}-26$ & $5.5 \mathrm{E}-27$ & 13. & 2.6 & 1938.19333 & $\mathrm{H} 1$ & $\mathrm{Q}$ & 11 & $\mathrm{~A} 1$ & 1 & 2 & $99 \%$ & 11 & A2 & 3 & 2 & $99 \%$ \\
\hline 3 & 114.52344 & $2.267 \mathrm{E}-25$ & $4.5 \mathrm{E}-26$ & 20. & 0.9 & 575.18407 & $\mathrm{CB}$ & $\mathrm{R}$ & 10 & $\mathrm{~F} 1$ & 1 & 1 & $100 \%$ & 11 & $\mathrm{~F} 2$ & 1 & 1 & $100 \%$ \\
\hline 3 & 114.53532 & $2.576 \mathrm{E}-25$ & $4.5 \mathrm{E}-26$ & 18. & -1.4 & 575.16984 & $\mathrm{CB}$ & $\mathrm{R}$ & 10 & $\mathrm{~F} 2$ & 2 & 1 & $100 \%$ & 11 & F1 & 1 & 1 & $100 \%$ \\
\hline 2 & 114.61438 & $1.686 \mathrm{E}-25$ & $1.2 \mathrm{E}-26$ & 7.1 & -8.0 & 575.27168 & $\mathrm{CB}$ & $\mathrm{R}$ & 10 & $\mathrm{E}$ & 2 & 1 & $100 \%$ & 11 & $\mathrm{E}$ & 1 & 1 & $100 \%$ \\
\hline 2 & 114.61714 & $2.930 \mathrm{E}-25$ & $1.8 \mathrm{E}-26$ & 6.1 & 3.5 & 575.25955 & $\mathrm{CB}$ & $\mathrm{R}$ & 10 & $\mathrm{~F} 1$ & 2 & 1 & $100 \%$ & 11 & $\mathrm{~F} 2$ & 2 & 1 & $100 \%$ \\
\hline 4 & 114.63941 & $7.343 \mathrm{E}-25$ & $2.0 \mathrm{E}-25$ & 28. & 4.9 & 575.22269 & $\mathrm{CB}$ & $\mathrm{R}$ & 10 & $\mathrm{~A} 1$ & 1 & 1 & $100 \%$ & 11 & A2 & 1 & 1 & $100 \%$ \\
\hline 2 & 114.65061 & $2.374 \mathrm{E}-25$ & $2.0 \mathrm{E}-26$ & 8.6 & -1.1 & 1521.96395 & $\mathrm{H} 1$ & $\mathrm{R}$ & 6 & $\mathrm{~A} 1$ & 1 & 2 & $98 \%$ & 7 & $\mathrm{~A} 2$ & 2 & 2 & $100 \%$ \\
\hline 4 & 114.67144 & $3.632 \mathrm{E}-25$ & $2.9 \mathrm{E}-26$ & 7.9 & 1.6 & 575.28518 & $\mathrm{CB}$ & $\mathrm{R}$ & 10 & $\mathrm{~F} 2$ & 3 & 1 & $100 \%$ & 11 & F1 & 2 & 1 & $100 \%$ \\
\hline 3 & 114.69262 & $6.598 \mathrm{E}-26$ & $1.6 \mathrm{E}-26$ & 24. & 20 . & 575.18407 & $\mathrm{CB}$ & $\mathrm{R}$ & 10 & $\mathrm{~F} 1$ & 1 & 1 & $100 \%$ & 11 & $\mathrm{~F} 2$ & 2 & 1 & $100 \%$ \\
\hline 1 & 114.87932 & $3.423 \mathrm{E}-26$ & $5.6 \mathrm{E}-27$ & 16. & -28 & 575.16984 & $\mathrm{CB}$ & $\mathrm{R}$ & 10 & $\mathrm{~F} 2$ & 2 & 1 & $100 \%$ & 11 & $\mathrm{~F} 1$ & 3 & 1 & $100 \%$ \\
\hline 3 & 114.92642 & $1.540 \mathrm{E}-25$ & $2.1 \mathrm{E}-26$ & 14. & 6.1 & 1521.46869 & $\mathrm{H} 1$ & $\mathrm{R}$ & 6 & $\mathrm{~F} 1$ & 2 & 2 & $98 \%$ & 7 & $\mathrm{~F} 2$ & 5 &  & $99 \%$ \\
\hline 3 & 114.97639 & $7.258 \mathrm{E}-26$ & $3.7 \mathrm{E}-26$ & 51. & -29 . & 1521.28438 & $\mathrm{H} 1$ & $\mathrm{R}$ & 6 & $\mathrm{E}$ & 2 & 2 & $98 \%$ & 7 & $\mathrm{E}$ & 4 & 2 & $99 \%$ \\
\hline 4 & 117.12457 & $3.327 \mathrm{E}-25$ & $2.3 \mathrm{E}-26$ & 7.0 & 4.7 & 1436.86503 & $\mathrm{H} 1$ & $\mathrm{R}$ & 5 & $\mathrm{~F} 1$ & 1 & 2 & $99 \%$ & 6 & $\mathrm{~F} 2$ & 4 & & $97 \%$ \\
\hline 4 & 117.61930 & $1.670 \mathrm{E}-25$ & $2.1 \mathrm{E}-26$ & 13. & -3.3 & 1437.20057 & $\mathrm{H} 1$ & $\mathrm{R}$ & 5 & $\mathrm{E}$ & 1 & 2 & $100 \%$ & 6 & $\mathrm{E}$ & 3 & 2 & $98 \%$ \\
\hline 4 & 118.07167 & $2.186 \mathrm{E}-25$ & $2.5 \mathrm{E}-26$ & 12 . & -4.9 & 1437.32117 & $\mathrm{H} 1$ & $\mathrm{R}$ & 5 & $\mathrm{~F} 2$ & 1 & 2 & $100 \%$ & 6 & F1 & 4 & 2 & $98 \%$ \\
\hline 4 & 118.98777 & $3.270 \mathrm{E}-25$ & $3.7 \mathrm{E}-26$ & 11. & -3.4 & 1437.49370 & $\mathrm{H} 1$ & $\mathrm{R}$ & 5 & $\mathrm{~A} 2$ & 1 & 2 & $100 \%$ & 6 & A1 & 2 & 2 & $99 \%$ \\
\hline
\end{tabular}


Table A.1: Continued

\begin{tabular}{|c|c|c|c|c|c|c|c|c|c|c|c|c|c|c|c|c|c|c|}
\hline$\overline{\overline{\#}}$ & Position & Intensity & $\overline{\text { Unc. }}$ & $\overline{\mathrm{U} / \%}$ & $\overline{\mathrm{O}-\mathrm{C} / \%}$ & $\overline{E "}$ & $\overline{\mathrm{Bd}}$ & $\overline{\mathrm{Br}}$ & $\overline{\text { J" }}$ & $\overline{C "}$ & $\overline{n "}$ & & $\overline{\# \text { \#vib" }}$ & $\overline{\bar{J}}$ & $\overline{\overline{\mathrm{C}}}$ & $\overline{\mathrm{n}}$ & & $\overline{\# \text { \#ib }}$ \\
\hline 3 & 124.76275 & $1.632 \mathrm{E}-25$ & $1.3 \mathrm{E}-26$ & 7.8 & 5.3 & 689.88606 & $\mathrm{CB}$ & $\mathrm{R}$ & 11 & $\mathrm{E}$ & 1 & 1 & $100 \%$ & 12 & $\mathrm{E}$ & 1 & $\overline{1}$ & $100 \%$ \\
\hline 3 & 124.77117 & $2.414 \mathrm{E}-25$ & $1.8 \mathrm{E}-26$ & 7.6 & 0.8 & 689.87668 & $\mathrm{CB}$ & $\mathrm{R}$ & 11 & $\mathrm{~F} 2$ & 2 & 1 & $100 \%$ & 12 & F1 & 1 & 1 & $100 \%$ \\
\hline 4 & 124.78389 & $4.350 \mathrm{E}-25$ & $1.6 \mathrm{E}-26$ & 3.6 & 0.9 & 689.86209 & $\mathrm{CB}$ & $\mathrm{R}$ & 11 & $\mathrm{~A} 2$ & 1 & 1 & $100 \%$ & 12 & A1 & 1 & 1 & $100 \%$ \\
\hline 4 & 124.86687 & $2.760 \mathrm{E}-25$ & $2.4 \mathrm{E}-26$ & 8.7 & 3.6 & 690.01741 & $\mathrm{CB}$ & $\mathrm{R}$ & 11 & F2 & 3 & 1 & $100 \%$ & 12 & $\mathrm{~F} 1$ & 2 & 1 & $100 \%$ \\
\hline 4 & 124.90983 & $3.801 \mathrm{E}-25$ & $2.1 \mathrm{E}-26$ & 5.4 & 0.2 & 689.95663 & $\mathrm{CB}$ & $\mathrm{R}$ & 11 & $\mathrm{~F} 1$ & 2 & 1 & $100 \%$ & 12 & $\mathrm{~F} 2$ & 1 & 1 & $100 \%$ \\
\hline 2 & 124.95360 & $2.366 \mathrm{E}-25$ & $1.2 \mathrm{E}-26$ & 5.2 & 3.9 & 690.03951 & $\mathrm{CB}$ & $\mathrm{R}$ & 11 & $\mathrm{E}$ & 2 & 1 & $100 \%$ & 12 & $\mathrm{E}$ & 2 & 1 & $100 \%$ \\
\hline 2 & 124.95887 & $3.365 \mathrm{E}-25$ & $9.9 \mathrm{E}-27$ & 2.9 & 5.2 & 690.04917 & $\mathrm{CB}$ & $\mathrm{R}$ & 11 & $\mathrm{~F} 1$ & 3 & 1 & $100 \%$ & 12 & F2 & 2 & 1 & $100 \%$ \\
\hline 4 & 125.28147 & $1.230 \mathrm{E}-25$ & $1.9 \mathrm{E}-26$ & 16. & 14. & 689.86209 & $\mathrm{CB}$ & $\mathrm{R}$ & 11 & $\mathrm{~A} 2$ & 1 & 1 & $100 \%$ & 12 & $\mathrm{~A} 1$ & 2 & 1 & $100 \%$ \\
\hline 4 & 131.54208 & $1.558 \mathrm{E}-25$ & $1.2 \mathrm{E}-26$ & 7.5 & 3.1 & 1593.02581 & $\mathrm{H} 1$ & $\mathrm{R}$ & 7 & $\mathrm{~F} 1$ & 3 & 2 & $97 \%$ & 8 & $\mathrm{~F} 2$ & 7 & 2 & $99 \%$ \\
\hline 4 & 131.62911 & $1.449 \mathrm{E}-25$ & $1.0 \mathrm{E}-26$ & 7.0 & -8.1 & 1592.75259 & H1 & $\mathrm{R}$ & 7 & $\mathrm{~F} 2$ & 2 & 2 & $97 \%$ & 8 & $\mathrm{~F} 1$ & 6 & 2 & $99 \%$ \\
\hline 3 & 133.57281 & $8.351 \mathrm{E}-26$ & $7.1 \mathrm{E}-27$ & 8.5 & -2.5 & 1640.20832 & $\mathrm{H} 1$ & $\mathrm{R}$ & 8 & A1 & 1 & 2 & $99 \%$ & 9 & $\mathrm{~A} 2$ & 2 & 2 & $98 \%$ \\
\hline 3 & 134.95865 & $2.026 \mathrm{E}-25$ & $1.0 \mathrm{E}-26$ & 5.1 & -3.3 & 814.88428 & $\mathrm{CB}$ & $\mathrm{R}$ & 12 & $\mathrm{~F} 1$ & 2 & 1 & $100 \%$ & 13 & F2 & 1 & 1 & $100 \%$ \\
\hline 3 & 134.97498 & $2.127 \mathrm{E}-25$ & $3.6 \mathrm{E}-27$ & 1.7 & -2.1 & 814.86645 & $\mathrm{CB}$ & $\mathrm{R}$ & 12 & $\mathrm{~F} 2$ & 1 & 1 & $100 \%$ & 13 & $\mathrm{~F} 1$ & 1 & 1 & $100 \%$ \\
\hline 2 & 135.06476 & $3.871 \mathrm{E}-25$ & $8.0 \mathrm{E}-27$ & 2.1 & -0.5 & 815.08895 & $\mathrm{CB}$ & $\mathrm{R}$ & 12 & $\mathrm{~A} 2$ & 1 & 1 & $100 \%$ & 13 & A1 & 1 & 1 & $100 \%$ \\
\hline 3 & 135.12831 & $2.870 \mathrm{E}-25$ & $5.2 \mathrm{E}-27$ & 1.8 & 3.2 & 815.00803 & $\mathrm{CB}$ & $\mathrm{R}$ & 12 & $\mathrm{~F} 2$ & 2 & 1 & $100 \%$ & 13 & F1 & 2 & 1 & $100 \%$ \\
\hline 3 & 135.13616 & $2.268 \mathrm{E}-25$ & $1.0 \mathrm{E}-26$ & 4.5 & 1.7 & 814.99312 & $\mathrm{CB}$ & $\mathrm{R}$ & 12 & $\mathrm{E}$ & 2 & 1 & $100 \%$ & 13 & $\mathrm{E}$ & 1 & 1 & $100 \%$ \\
\hline 3 & 135.18891 & $2.471 \mathrm{E}-25$ & $1.7 \mathrm{E}-26$ & 6.8 & -3.1 & 815.11586 & $\mathrm{CB}$ & $\mathrm{R}$ & 12 & $\mathrm{~F} 2$ & 3 & 1 & $100 \%$ & 13 & F1 & 3 & 1 & $100 \%$ \\
\hline 3 & 135.24148 & $5.208 \mathrm{E}-25$ & $2.4 \mathrm{E}-26$ & 4.6 & -1.3 & 815.14356 & $\mathrm{CB}$ & $\mathrm{R}$ & 12 & A1 & 2 & 1 & $100 \%$ & 13 & $\mathrm{~A} 2$ & 1 & 1 & $100 \%$ \\
\hline 2 & 135.29673 & $8.246 \mathrm{E}-26$ & $1.0 \mathrm{E}-26$ & 12. & 4.9 & 815.00803 & $\mathrm{CB}$ & $\mathrm{R}$ & 12 & $\mathrm{~F} 2$ & 2 & 1 & $100 \%$ & 13 & $\mathrm{~F} 1$ & 3 & 1 & $100 \%$ \\
\hline 1 & 135.65576 & $3.389 \mathrm{E}-26$ & $1.7 \mathrm{E}-27$ & 4.9 & -15 & 814.86645 & $\mathrm{CB}$ & $\mathrm{R}$ & 12 & $\mathrm{~F} 2$ & 1 & 1 & $100 \%$ & 13 & F1 & 4 & 1 & $100 \%$ \\
\hline 1 & 135.73905 & $3.190 \mathrm{E}-26$ & $7.6 \mathrm{E}-28$ & 2.4 & 6.7 & 814.64599 & $\mathrm{CB}$ & $\mathrm{R}$ & 12 & A1 & 1 & 1 & $100 \%$ & 13 & $\mathrm{~A} 2$ & 1 & 1 & $100 \%$ \\
\hline 4 & 136.07656 & $3.494 \mathrm{E}-25$ & $1.7 \mathrm{E}-26$ & 5.0 & -1.5 & 1494.09862 & $\mathrm{H} 1$ & $\mathrm{R}$ & 6 & $\mathrm{~F} 2$ & 1 & 2 & $99 \%$ & 7 & F1 & 5 & 2 & $97 \%$ \\
\hline 4 & 136.41416 & $2.250 \mathrm{E}-25$ & $2.8 \mathrm{E}-26$ & 13. & 0.6 & 1494.19605 & $\mathrm{H} 1$ & $\mathrm{R}$ & 6 & $\mathrm{E}$ & 1 & 2 & $99 \%$ & 7 & $\mathrm{E}$ & 3 & & $97 \%$ \\
\hline 3 & 137.08228 & $2.527 \mathrm{E}-25$ & $7.4 \mathrm{E}-27$ & 2.9 & -2.4 & 1494.72267 & $\mathrm{H} 1$ & $\mathrm{R}$ & 6 & $\mathrm{~F} 1$ & 1 & 2 & $99 \%$ & 7 & $\mathrm{~F} 2$ & 4 & 2 & $97 \%$ \\
\hline 3 & 137.84405 & $1.364 \mathrm{E}-25$ & $5.0 \mathrm{E}-27$ & 3.6 & -0.5 & 1729.88932 & $\mathrm{H} 1$ & $\mathrm{R}$ & 9 & $\mathrm{~A} 2$ & 1 & 2 & $99 \%$ & 10 & A1 & 2 & 2 & $94 \%$ \\
\hline 3 & 137.85432 & $7.932 \mathrm{E}-26$ & $2.1 \mathrm{E}-26$ & 26. & 1.0 & 1729.80843 & $\mathrm{H} 1$ & $\mathrm{R}$ & 9 & $\mathrm{~F} 2$ & 2 & 2 & $99 \%$ & 10 & F1 & 3 & 2 & $94 \%$ \\
\hline 3 & 137.86736 & $5.267 \mathrm{E}-26$ & $3.9 \mathrm{E}-27$ & 7.5 & 2.4 & 1729.76129 & $\mathrm{H} 1$ & $\mathrm{R}$ & 9 & $\mathrm{E}$ & 2 & 2 & $99 \%$ & 10 & $\mathrm{E}$ & 2 & 2 & $94 \%$ \\
\hline 1 & 138.43967 & $1.766 \mathrm{E}-25$ & $8.6 \mathrm{E}-27$ & 4.9 & -21 . & 1494.94792 & $\mathrm{H} 1$ & $\mathrm{R}$ & 6 & $\mathrm{~F} 2$ & 2 & 2 & $100 \%$ & 7 & $\mathrm{~F} 1$ & 6 & & $98 \%$ \\
\hline 2 & 145.09922 & $2.920 \mathrm{E}-25$ & $3.2 \mathrm{E}-27$ & 1.1 & 3.6 & 950.15371 & $\mathrm{CB}$ & $\mathrm{R}$ & 13 & A1 & 1 & 1 & $100 \%$ & 14 & $\mathrm{~A} 2$ & 1 & 1 & $100 \%$ \\
\hline 3 & 145.11543 & $1.761 \mathrm{E}-25$ & $1.6 \mathrm{E}-26$ & 9.1 & 2.4 & 950.13634 & $\mathrm{CB}$ & $\mathrm{R}$ & 13 & $\mathrm{~F} 1$ & 2 & 1 & $100 \%$ & 14 & F2 & 1 & 1 & $100 \%$ \\
\hline 3 & 145.12193 & $1.244 \mathrm{E}-25$ & $2.0 \mathrm{E}-26$ & 16. & 6.6 & 950.12928 & $\mathrm{CB}$ & $\mathrm{R}$ & 13 & $\mathrm{E}$ & 1 & 1 & $100 \%$ & 14 & $\mathrm{E}$ & 1 & 1 & $100 \%$ \\
\hline 4 & 145.29512 & $2.128 \mathrm{E}-25$ & $1.1 \mathrm{E}-26$ & 5.0 & 0.7 & 950.33681 & $\mathrm{CB}$ & $\mathrm{R}$ & 13 & $\mathrm{~F} 2$ & 2 & 1 & $100 \%$ & 14 & $\mathrm{~F} 1$ & 1 & 1 & $100 \%$ \\
\hline 4 & 145.31437 & $2.656 \mathrm{E}-25$ & $1.8 \mathrm{E}-26$ & 6.7 & 0.7 & 950.30477 & $\mathrm{CB}$ & $\mathrm{R}$ & 13 & F1 & 3 & 1 & $100 \%$ & 14 & $\mathrm{~F} 2$ & 2 & 1 & $100 \%$ \\
\hline 3 & 145.38186 & $1.930 \mathrm{E}-25$ & $8.6 \mathrm{E}-27$ & 4.4 & -0.8 & 950.48723 & $\mathrm{CB}$ & $\mathrm{R}$ & 13 & $\mathrm{~F} 2$ & 3 & 1 & $100 \%$ & 14 & $\mathrm{~F} 1$ & 2 & 1 & $100 \%$ \\
\hline 3 & 145.38969 & $1.388 \mathrm{E}-25$ & $1.5 \mathrm{E}-26$ & 11. & -3.4 & 950.50491 & $\mathrm{CB}$ & $\mathrm{R}$ & 13 & $\mathrm{E}$ & 2 & 1 & $100 \%$ & 14 & $\mathrm{E}$ & 2 & 1 & $100 \%$ \\
\hline 4 & 145.44356 & $5.557 \mathrm{E}-25$ & $1.5 \mathrm{E}-26$ & 2.8 & -1.3 & 950.38504 & $\mathrm{CB}$ & $\mathrm{R}$ & 13 & $\mathrm{~A} 2$ & 1 & 1 & $100 \%$ & 14 & A1 & 1 & 1 & $100 \%$ \\
\hline 4 & 145.45911 & $2.502 \mathrm{E}-25$ & $2.4 \mathrm{E}-26$ & 9.6 & -0.2 & 950.52221 & $\mathrm{CB}$ & $\mathrm{R}$ & 13 & $\mathrm{~F} 1$ & 4 & 1 & $100 \%$ & 14 & $\mathrm{~F} 2$ & 3 & 1 & $100 \%$ \\
\hline 4 & 145.53228 & $7.812 \mathrm{E}-26$ & $8.9 \mathrm{E}-27$ & 11. & 7.6 & 950.33681 & $\mathrm{CB}$ & $\mathrm{R}$ & 13 & $\mathrm{~F} 2$ & 2 & 1 & $100 \%$ & 14 & $\mathrm{~F} 1$ & 2 & 1 & $100 \%$ \\
\hline 4 & 148.46977 & $9.857 \mathrm{E}-26$ & $2.7 \mathrm{E}-26$ & 27 . & 2.4 & 1674.48632 & $\mathrm{H} 1$ & $\mathrm{R}$ & 8 & $\mathrm{E}$ & 2 & 2 & $96 \%$ & 9 & $\mathrm{E}$ & 5 & 2 & $99 \%$ \\
\hline 4 & 148.50492 & $1.645 \mathrm{E}-25$ & $3.0 \mathrm{E}-26$ & 18. & 13. & 1674.39048 & $\mathrm{H} 1$ & $\mathrm{R}$ & 8 & $\mathrm{~F} 2$ & 3 & 2 & $96 \%$ & 9 & F1 & 7 & 2 & $99 \%$ \\
\hline 4 & 148.54381 & $2.412 \mathrm{E}-25$ & $2.2 \mathrm{E}-26$ & 9.2 & -2.6 & 1674.21674 & $\mathrm{H} 1$ & $\mathrm{R}$ & 8 & $\mathrm{~A} 2$ & 1 & 2 & $96 \%$ & 9 & A1 & 2 & 2 & $99 \%$ \\
\hline 1 & 153.10148 & $7.379 \mathrm{E}-26$ & $2.7 \mathrm{E}-27$ & 3.6 & 21. & 1773.78112 & $\mathrm{H} 1$ & $\mathrm{R}$ & 9 & A2 & 2 & 2 & $98 \%$ & 10 & A1 & 3 & 2 & $97 \%$ \\
\hline 3 & 154.52536 & $6.270 \mathrm{E}-25$ & $3.9 \mathrm{E}-26$ & 6.2 & 0.8 & 1561.56706 & $\mathrm{H} 1$ & $\mathrm{R}$ & 7 & $\mathrm{~A} 2$ & 1 & 2 & $99 \%$ & 8 & A1 & 2 & & $95 \%$ \\
\hline 4 & 154.91492 & $3.362 \mathrm{E}-25$ & $3.2 \mathrm{E}-26$ & 9.4 & -3.9 & 1561.71914 & $\mathrm{H} 1$ & $\mathrm{R}$ & 7 & $\mathrm{~F} 2$ & 1 & 2 & $99 \%$ & 8 & $\mathrm{~F} 1$ & 5 & 2 & $96 \%$ \\
\hline 3 & 155.20508 & $1.174 \mathrm{E}-25$ & $1.5 \mathrm{E}-26$ & 13. & -7.7 & 1095.63193 & $\mathrm{CB}$ & $\mathrm{R}$ & 14 & $\mathrm{~F} 1$ & 1 & 1 & $100 \%$ & 15 & $\mathrm{~F} 2$ & 1 & 1 & $100 \%$ \\
\hline 3 & 155.21702 & $1.238 \mathrm{E}-25$ & $4.5 \mathrm{E}-27$ & 3.7 & -4.5 & 1095.61913 & $\mathrm{CB}$ & $\mathrm{R}$ & 14 & $\mathrm{~F} 2$ & 2 & 1 & $100 \%$ & 15 & F1 & 1 & 1 & $100 \%$ \\
\hline 4 & 155.43277 & $1.694 \mathrm{E}-25$ & $2.3 \mathrm{E}-26$ & 14. & -8.2 & 1095.86909 & $\mathrm{CB}$ & $\mathrm{R}$ & 14 & $\mathrm{~F} 1$ & 2 & 1 & $100 \%$ & 15 & $\mathrm{~F} 2$ & 2 & 1 & $100 \%$ \\
\hline 4 & 155.46268 & $3.485 \mathrm{E}-25$ & $1.6 \mathrm{E}-26$ & 4.5 & -0.5 & 1095.82859 & $\mathrm{CB}$ & $\mathrm{R}$ & 14 & A1 & 1 & 1 & $100 \%$ & 15 & $\mathrm{~A} 2$ & 1 & 1 & $100 \%$ \\
\hline 4 & 155.51376 & $1.512 \mathrm{E}-25$ & $1.1 \mathrm{E}-26$ & 6.9 & -0.8 & 1096.13287 & $\mathrm{CB}$ & $\mathrm{R}$ & 14 & $\mathrm{~F} 1$ & 3 & 1 & $100 \%$ & 15 & $\mathrm{~F} 2$ & 3 & 1 & $100 \%$ \\
\hline
\end{tabular}


Table A.1: Continued

\begin{tabular}{|c|c|c|c|c|c|c|c|c|c|c|c|c|c|c|c|c|c|c|}
\hline$\overline{\#}$ & $\overline{\text { Position }}$ & Intensity & $\overline{\text { Unc. }}$ & $\overline{\mathrm{U} / \%}$ & $\overline{\mathrm{O}-\mathrm{C} / \%}$ & $\overline{E "}$ & $\overline{\mathrm{Bd}}$ & $\overline{\overline{\mathrm{Br}}}$ & $\overline{\text { J" }}$ & 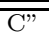 & $\overline{\text { n" }}$ & & $\overline{\text { \#vib" }}$ & $\overline{\mathrm{J}}$ & $\overline{\overline{\mathrm{C}}}$ & $\overline{\mathrm{n}}$ & & $\overline{\# \text { \#ib }}$ \\
\hline 4 & 155.60915 & $2.216 \mathrm{E}-25$ & $4.3 \mathrm{E}-26$ & 19. & -8.5 & 1095.98132 & $\overline{\mathrm{CB}}$ & $\overline{\mathrm{R}}$ & 14 & F2 & 3 & 1 & $100 \%$ & 15 & F1 & 2 & 1 & $100 \%$ \\
\hline 4 & 155.62286 & $1.143 \mathrm{E}-25$ & $2.5 \mathrm{E}-26$ & 22. & -2.9 & 1096.15684 & $\mathrm{CB}$ & $\mathrm{R}$ & 14 & $\mathrm{E}$ & 3 & 1 & $100 \%$ & 15 & $\mathrm{E}$ & 2 & 1 & $100 \%$ \\
\hline 4 & 155.63624 & $1.896 \mathrm{E}-25$ & $2.2 \mathrm{E}-26$ & 11. & 5.8 & 1096.17086 & $\mathrm{CB}$ & $\mathrm{R}$ & 14 & $\mathrm{~F} 2$ & 4 & 1 & $100 \%$ & 15 & F1 & 3 & 1 & $100 \%$ \\
\hline 4 & 156.07978 & $4.081 \mathrm{E}-25$ & $5.2 \mathrm{E}-26$ & 13. & -1.6 & 1562.57412 & H1 & $\mathrm{R}$ & 7 & A1 & 1 & 2 & $99 \%$ & 8 & $\mathrm{~A} 2$ & 2 & 2 & $97 \%$ \\
\hline 1 & 156.23286 & $5.215 \mathrm{E}-26$ & $3.2 \mathrm{E}-27$ & 6.2 & -14 & 1095.82859 & CB & $\mathrm{R}$ & 14 & A1 & 1 & 1 & $100 \%$ & 15 & A2 & 2 & 1 & $100 \%$ \\
\hline 4 & 157.64383 & $2.107 \mathrm{E}-25$ & $1.9 \mathrm{E}-26$ & 8.9 & 0.1 & 1562.78797 & $\mathrm{H} 1$ & $\mathrm{R}$ & 7 & F1 & 2 & 2 & $99 \%$ & 8 & $\mathrm{~F} 2$ & 6 & 2 & $98 \%$ \\
\hline 2 & 162.96860 & $3.754 \mathrm{E}-26$ & $9.1 \mathrm{E}-27$ & 24. & 14. & 1938.25388 & H1 & $\mathrm{R}$ & 11 & $\mathrm{E}$ & 2 & 2 & $99 \%$ & 12 & $\mathrm{E}$ & 3 & 2 & $91 \%$ \\
\hline 2 & 162.97687 & $6.350 \mathrm{E}-26$ & $1.0 \mathrm{E}-26$ & 16. & 29 . & 1938.23462 & $\mathrm{H} 1$ & $\mathrm{R}$ & 11 & F1 & 3 & 2 & $99 \%$ & 12 & $\mathrm{~F} 2$ & 4 & 2 & $91 \%$ \\
\hline 3 & 162.99640 & $8.925 \mathrm{E}-26$ & $2.5 \mathrm{E}-26$ & 28. & 10.0 & 1938.19333 & H1 & $\mathrm{R}$ & 11 & A1 & 1 & 2 & $99 \%$ & 12 & A2 & 1 & 2 & $91 \%$ \\
\hline 2 & 165.24669 & $6.758 \mathrm{E}-26$ & $7.2 \mathrm{E}-27$ & 11. & 15. & 1251.30765 & CB & $\mathrm{R}$ & 15 & $\mathrm{E}$ & 1 & 1 & $100 \%$ & 16 & $\mathrm{E}$ & 1 & 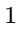 & $100 \%$ \\
\hline 2 & 165.25216 & $9.349 \mathrm{E}-26$ & $8.7 \mathrm{E}-27$ & 9.3 & 5.9 & 1251.30186 & $\mathrm{CB}$ & $\mathrm{R}$ & 15 & $\mathrm{~F} 2$ & 2 & 1 & $100 \%$ & 16 & $\mathrm{~F} 1$ & 1 & 1 & $100 \%$ \\
\hline 2 & 165.26211 & $1.488 \mathrm{E}-25$ & $9.1 \mathrm{E}-27$ & 6.1 & -0.0 & 1251.29127 & $\mathrm{CB}$ & $\mathrm{R}$ & 15 & A2 & 1 & 1 & $100 \%$ & 16 & $\mathrm{~A} 1$ & 1 & 1 & $100 \%$ \\
\hline 3 & 165.48246 & $1.189 \mathrm{E}-25$ & $1.9 \mathrm{E}-26$ & 16. & -5.7 & 1251.64663 & $\mathrm{CB}$ & $\mathrm{R}$ & 15 & $\mathrm{~F} 2$ & 3 & 1 & $100 \%$ & 16 & F1 & 2 & 1 & $100 \%$ \\
\hline 3 & 165.52922 & $1.403 \mathrm{E}-25$ & $2.3 \mathrm{E}-26$ & 16. & 3.1 & 1251.59047 & $\mathrm{CB}$ & $\mathrm{R}$ & 15 & $\mathrm{~F} 1$ & 2 & 1 & $100 \%$ & 16 & $\mathrm{~F} 2$ & 1 & 1 & $100 \%$ \\
\hline 3 & 165.57721 & $1.793 \mathrm{E}-25$ & $1.6 \mathrm{E}-26$ & 9.1 & 1.9 & 1252.00188 & $\mathrm{CB}$ & $\mathrm{R}$ & 15 & A1 & 1 & 1 & $100 \%$ & 16 & A2 & 1 & 1 & $100 \%$ \\
\hline 3 & 165.60785 & $1.169 \mathrm{E}-25$ & $1.8 \mathrm{E}-26$ & 16. & -5.7 & 1766.04623 & $\mathrm{H} 1$ & $\mathrm{R}$ & 9 & $\mathrm{~F} 1$ & 3 & 2 & $95 \%$ & 10 & $\mathrm{~F} 2$ & 8 & 2 & $99 \%$ \\
\hline 3 & 165.64127 & $1.331 \mathrm{E}-25$ & $2.6 \mathrm{E}-26$ & 20. & 6.8 & 1765.92945 & $\mathrm{H} 1$ & $\mathrm{R}$ & 9 & F2 & 3 & 2 & $95 \%$ & 10 & F1 & 8 & 2 & $99 \%$ \\
\hline 2 & 165.71246 & $1.466 \mathrm{E}-25$ & $2.8 \mathrm{E}-26$ & 19. & 5.4 & 1251.80710 & $\mathrm{CB}$ & $\mathrm{R}$ & 15 & F1 & 3 & 1 & $100 \%$ & 16 & $\mathrm{~F} 2$ & 2 & 1 & $100 \%$ \\
\hline 2 & 165.71962 & $1.055 \mathrm{E}-25$ & $1.0 \mathrm{E}-26$ & 9.8 & -5.5 & 1251.77970 & $\mathrm{CB}$ & $\mathrm{R}$ & 15 & $\mathrm{E}$ & 2 & 1 & $100 \%$ & 16 & $\mathrm{E}$ & 2 & 1 & $100 \%$ \\
\hline 2 & 165.72524 & $1.011 \mathrm{E}-25$ & $1.4 \mathrm{E}-26$ & 14. & -3.4 & 1252.02761 & $\mathrm{CB}$ & $\mathrm{R}$ & 15 & F1 & 4 & 1 & $100 \%$ & 16 & $\mathrm{~F} 2$ & 3 & 1 & $100 \%$ \\
\hline 3 & 165.76086 & $1.348 \mathrm{E}-25$ & $1.2 \mathrm{E}-26$ & 8.8 & 12. & 1252.04625 & $\mathrm{CB}$ & $\mathrm{R}$ & 15 & $\mathrm{~F} 2$ & 4 & 1 & $100 \%$ & 16 & $\mathrm{~F} 1$ & 3 & 1 & $100 \%$ \\
\hline 3 & 165.80353 & $2.266 \mathrm{E}-25$ & $2.4 \mathrm{E}-26$ & 10. & 4.4 & 1252.06145 & $\mathrm{CB}$ & $\mathrm{R}$ & 15 & $\mathrm{~A} 2$ & 2 & 1 & $100 \%$ & 16 & $\mathrm{~A} 1$ & 2 & 1 & $100 \%$ \\
\hline 4 & 173.04869 & $3.489 \mathrm{E}-25$ & $3.6 \mathrm{E}-26$ & 10. & 4.6 & 1639.50861 & $\mathrm{H} 1$ & $\mathrm{R}$ & 8 & $\mathrm{~F} 2$ & 1 & 2 & $99 \%$ & 9 & $\mathrm{~F} 1$ & 5 & & $94 \%$ \\
\hline 3 & 173.54862 & $1.986 \mathrm{E}-25$ & $1.5 \mathrm{E}-26$ & 7.5 & -3.3 & 1639.74547 & H1 & $\mathrm{R}$ & 8 & $\mathrm{E}$ & 1 & 2 & $99 \%$ & 9 & $\mathrm{E}$ & 4 & 2 & $95 \%$ \\
\hline 4 & 174.06745 & $3.047 \mathrm{E}-25$ & $3.7 \mathrm{E}-26$ & 12. & 9.7 & 1639.90401 & H1 & $\mathrm{R}$ & 8 & F1 & 1 & 2 & $99 \%$ & 9 & $\mathrm{~F} 2$ & 6 & 2 & $95 \%$ \\
\hline 2 & 175.23026 & $6.572 \mathrm{E}-26$ & $8.4 \mathrm{E}-27$ & 13. & 17. & 1417.12909 & $\mathrm{CB}$ & $\mathrm{R}$ & 16 & F1 & 2 & 1 & $100 \%$ & 17 & $\mathrm{~F} 2$ & 1 & 1 & $100 \%$ \\
\hline 2 & 175.23920 & $5.148 \mathrm{E}-26$ & $4.8 \mathrm{E}-27$ & 9.2 & -8.9 & 1417.11969 & $\mathrm{CB}$ & $\mathrm{R}$ & 16 & $\mathrm{~F} 2$ & 1 & 1 & $100 \%$ & 17 & F1 & 1 & 1 & $100 \%$ \\
\hline 3 & 175.47690 & $1.414 \mathrm{E}-25$ & $1.6 \mathrm{E}-26$ & 11. & 4.2 & 1417.57909 & $\mathrm{CB}$ & $\mathrm{R}$ & 16 & $\mathrm{~A} 2$ & 1 & 1 & $100 \%$ & 17 & $\mathrm{~A} 1$ & 1 & 1 & $100 \%$ \\
\hline 3 & 175.52873 & $8.728 \mathrm{E}-26$ & $2.8 \mathrm{E}-26$ & 32. & 4.2 & 1417.51956 & $\mathrm{CB}$ & $\mathrm{R}$ & 16 & F2 & 2 & 1 & $100 \%$ & 17 & F1 & 2 & 1 & $100 \%$ \\
\hline 2 & 175.54531 & $6.748 \mathrm{E}-26$ & $2.8 \mathrm{E}-26$ & 42. & 15. & 1417.49932 & $\mathrm{CB}$ & $\mathrm{R}$ & 16 & $\mathrm{E}$ & 2 & 1 & $100 \%$ & 17 & $\mathrm{E}$ & 1 & 1 & $100 \%$ \\
\hline 2 & 175.75462 & $8.168 \mathrm{E}-26$ & $1.7 \mathrm{E}-26$ & 20 . & -2.9 & 1417.80711 & $\mathrm{CB}$ & $\mathrm{R}$ & 16 & F1 & 3 & 1 & $100 \%$ & 17 & $\mathrm{~F} 2$ & 2 & 1 & $100 \%$ \\
\hline 1 & 175.77014 & $1.052 \mathrm{E}-25$ & $3.9 \mathrm{E}-27$ & 3.7 & 3.3 & 1417.75285 & $\mathrm{CB}$ & $\mathrm{R}$ & 16 & F2 & 3 & 1 & $100 \%$ & 17 & F1 & 3 & 1 & $100 \%$ \\
\hline 2 & 175.77944 & $5.211 \mathrm{E}-26$ & $7.4 \mathrm{E}-27$ & 14. & -18 & 1418.09887 & $\mathrm{CB}$ & $\mathrm{R}$ & 16 & F1 & 4 & 1 & $100 \%$ & 17 & $\mathrm{~F} 2$ & 3 & 1 & $100 \%$ \\
\hline 2 & 175.80961 & $4.971 \mathrm{E}-26$ & $1.0 \mathrm{E}-26$ & 21. & 1.1 & 1418.11850 & $\mathrm{CB}$ & $\mathrm{R}$ & 16 & $\mathrm{E}$ & 3 & 1 & $100 \%$ & 17 & $\mathrm{E}$ & 2 & 1 & $100 \%$ \\
\hline 2 & 175.88877 & $8.307 \mathrm{E}-26$ & $8.5 \mathrm{E}-27$ & 10. & 3.1 & 1418.13715 & $\mathrm{CB}$ & $\mathrm{R}$ & 16 & $\mathrm{~F} 2$ & 4 & 1 & $100 \%$ & 17 & $\mathrm{~F} 1$ & 4 & 1 & $100 \%$ \\
\hline 2 & 175.91944 & $1.914 \mathrm{E}-25$ & $1.4 \mathrm{E}-26$ & 7.6 & -5.5 & 1417.86498 & $\mathrm{CB}$ & $\mathrm{R}$ & 16 & $\mathrm{~A} 1$ & 2 & 1 & $100 \%$ & 17 & $\mathrm{~A} 2$ & 1 & 1 & $100 \%$ \\
\hline 4 & 176.79514 & $1.983 \mathrm{E}-25$ & $2.5 \mathrm{E}-26$ & 13. & 9.4 & 1641.04784 & H1 & $\mathrm{R}$ & 8 & $\mathrm{~F} 1$ & 2 & 2 & $99 \%$ & 9 & $\mathrm{~F} 2$ & 7 & 2 & $97 \%$ \\
\hline 4 & 177.35729 & $1.931 \mathrm{E}-25$ & $9.0 \mathrm{E}-27$ & 4.7 & 7.4 & 1641.16444 & $\mathrm{H} 1$ & $\mathrm{R}$ & 8 & $\mathrm{~F} 2$ & 2 & 2 & $99 \%$ & 9 & $\mathrm{~F} 1$ & 6 & 2 & $97 \%$ \\
\hline 3 & 182.92118 & $1.595 \mathrm{E}-25$ & $1.3 \mathrm{E}-26$ & 8.0 & -1.5 & 1867.73337 & $\mathrm{H} 1$ & $\mathrm{R}$ & 10 & A1 & 2 & 2 & $94 \%$ & 11 & $\mathrm{~A} 2$ & 3 & 2 & $99 \%$ \\
\hline 2 & 182.93861 & $1.017 \mathrm{E}-25$ & $7.3 \mathrm{E}-27$ & 7.2 & 4.4 & 1867.66276 & $\mathrm{H} 1$ & $\mathrm{R}$ & 10 & F1 & 3 & 2 & $94 \%$ & 11 & $\mathrm{~F} 2$ & 8 & 2 & $99 \%$ \\
\hline 2 & 182.94507 & $7.552 \mathrm{E}-26$ & $4.6 \mathrm{E}-27$ & 6.0 & 16. & 1867.62865 & $\mathrm{H} 1$ & $\mathrm{R}$ & 10 & $\mathrm{E}$ & 2 & 2 & $94 \%$ & 11 & $\mathrm{E}$ & 6 & 2 & $99 \%$ \\
\hline 1 & 185.14892 & $5.447 \mathrm{E}-26$ & $1.2 \mathrm{E}-27$ & 2.2 & -2.0 & 1593.05599 & $\mathrm{CB}$ & $\mathrm{R}$ & 17 & A1 & 1 & 1 & $100 \%$ & 18 & A2 & 1 & 1 & $100 \%$ \\
\hline 1 & 185.15627 & $2.560 \mathrm{E}-26$ & $1.2 \mathrm{E}-27$ & 4.7 & -23 & 1593.04830 & $\mathrm{CB}$ & $\mathrm{R}$ & 17 & F1 & 2 & 1 & $100 \%$ & 18 & $\mathrm{~F} 2$ & 1 & 1 & $100 \%$ \\
\hline 1 & 185.15978 & $3.178 \mathrm{E}-26$ & $1.9 \mathrm{E}-27$ & 6.0 & 42. & 1593.04462 & $\mathrm{CB}$ & $\mathrm{R}$ & 17 & $\mathrm{E}$ & 1 & 1 & $100 \%$ & 18 & $\mathrm{E}$ & 1 & 1 & $100 \%$ \\
\hline 1 & 185.72296 & $3.828 \mathrm{E}-26$ & $1.1 \mathrm{E}-27$ & 3.0 & 5.7 & 1593.92810 & $\mathrm{CB}$ & $\mathrm{R}$ & 17 & $\mathrm{E}$ & 2 & 1 & $100 \%$ & 18 & $\mathrm{E}$ & 2 & 1 & $100 \%$ \\
\hline 1 & 185.75272 & $5.439 \mathrm{E}-26$ & $2.0 \mathrm{E}-27$ & 3.8 & -5.4 & 1593.87831 & $\mathrm{CB}$ & $\mathrm{R}$ & 17 & $\mathrm{~F} 2$ & 3 & 1 & $100 \%$ & 18 & $\mathrm{~F} 1$ & 2 & 1 & $100 \%$ \\
\hline 1 & 185.77760 & $4.182 \mathrm{E}-26$ & $2.3 \mathrm{E}-27$ & 5.6 & 1.8 & 1594.34467 & $\mathrm{CB}$ & $\mathrm{R}$ & 17 & $\mathrm{~F} 2$ & 4 & 1 & $100 \%$ & 18 & $\mathrm{~F} 1$ & 3 & 1 & $100 \%$ \\
\hline 3 & 185.81261 & $1.109 \mathrm{E}-25$ & $6.3 \mathrm{E}-27$ & 5.7 & -3.7 & 1593.78442 & $\mathrm{CB}$ & $\mathrm{R}$ & 17 & $\mathrm{~A} 2$ & 1 & 1 & $100 \%$ & 18 & $\mathrm{~A} 1$ & 1 & 1 & $100 \%$ \\
\hline 2 & 185.95843 & $6.835 \mathrm{E}-26$ & $1.1 \mathrm{E}-26$ & 16. & -3.6 & 1594.02591 & $\mathrm{CB}$ & $\mathrm{R}$ & 17 & F1 & 4 & 1 & $100 \%$ & 18 & $\mathrm{~F} 2$ & 3 & 1 & $100 \%$ \\
\hline
\end{tabular}


Table A.1: Continued

\begin{tabular}{|c|c|c|c|c|c|c|c|c|c|c|c|c|c|c|c|c|c|c|}
\hline \# & Position & Intensity & Unc. & $\overline{\mathrm{U} / \%}$ & $\mathrm{O}-\mathrm{C} / \%$ & E" & $\mathrm{Bd}$ & $\mathrm{Br}$ & J" & C" & n" & & tvib" & $\overline{\mathrm{J}}$ & $\mathrm{C}$ & $\overline{\mathrm{n}}$ & & \#vib \\
\hline 1 & 191.09868 & $2.669 \mathrm{E}-25$ & $3.8 \mathrm{E}-27$ & 1.4 & -4.2 & 1727.74303 & $\mathrm{H} 1$ & $\mathrm{R}$ & $\overline{9}$ & F1 & 1 & 2 & $98 \%$ & 10 & $\mathrm{~F} 2$ & 6 & 2 & $93 \%$ \\
\hline 4 & 191.49164 & $1.789 \mathrm{E}-25$ & $1.3 \mathrm{E}-26$ & 7.0 & 0.8 & 1727.84465 & $\mathrm{H} 1$ & $\mathrm{R}$ & 9 & $\mathrm{E}$ & 1 & 2 & $98 \%$ & 10 & $\mathrm{E}$ & 4 & 2 & $93 \%$ \\
\hline 4 & 192.11636 & $2.631 \mathrm{E}-25$ & $1.8 \mathrm{E}-26$ & 7.0 & 8.9 & 1728.19007 & H1 & $\mathrm{R}$ & 9 & $\mathrm{~F} 2$ & 1 & 2 & $99 \%$ & 10 & $\mathrm{~F} 1$ & 6 & 2 & $94 \%$ \\
\hline 4 & 194.81652 & $2.095 \mathrm{E}-25$ & $1.1 \mathrm{E}-26$ & 5.3 & 0.2 & 1728.59555 & $\mathrm{H} 1$ & $\mathrm{R}$ & 9 & $\mathrm{~F} 1$ & 2 & 2 & $99 \%$ & 10 & $\mathrm{~F} 2$ & 7 & 2 & $96 \%$ \\
\hline 1 & 195.36349 & $1.843 \mathrm{E}-26$ & $9.4 \mathrm{E}-28$ & 5.1 & -3.0 & 1779.65106 & $\mathrm{CB}$ & $\mathrm{R}$ & 18 & $\mathrm{E}$ & 2 & 1 & $100 \%$ & 19 & $\mathrm{E}$ & 1 & 1 & $100 \%$ \\
\hline 1 & 195.38122 & $2.301 \mathrm{E}-26$ & $9.9 \mathrm{E}-28$ & 4.3 & -20 & 1779.63103 & $\mathrm{CB}$ & $\mathrm{R}$ & 18 & F1 & 2 & 1 & $100 \%$ & 19 & $\mathrm{~F} 2$ & 2 & 1 & $100 \%$ \\
\hline 2 & 195.41070 & $4.622 \mathrm{E}-26$ & $4.7 \mathrm{E}-27$ & 10. & -6.5 & 1779.59703 & $\mathrm{CB}$ & $\mathrm{R}$ & 18 & $\mathrm{~A} 1$ & 1 & 1 & $100 \%$ & 19 & $\mathrm{~A} 2$ & 1 & 1 & $100 \%$ \\
\hline 1 & 195.69065 & $4.795 \mathrm{E}-26$ & $1.6 \mathrm{E}-27$ & 3.3 & 24. & 1780.70698 & $\mathrm{CB}$ & $\mathrm{R}$ & 18 & A2 & 2 & 1 & $100 \%$ & 19 & A1 & 1 & 1 & $100 \%$ \\
\hline 2 & 195.74041 & $3.295 \mathrm{E}-26$ & $0.0 \mathrm{E}+00$ & 0.0 & -8.5 & 1779.98434 & $\mathrm{CB}$ & $\mathrm{R}$ & 18 & $\mathrm{~F} 2$ & 3 & 1 & $100 \%$ & 19 & $\mathrm{~F} 1$ & 2 & 1 & $100 \%$ \\
\hline 4 & 196.15405 & $9.896 \mathrm{E}-26$ & $1.2 \mathrm{E}-26$ & 12. & 2.9 & 1729.76129 & $\mathrm{H} 1$ & $\mathrm{R}$ & 9 & $\mathrm{E}$ & 2 & 2 & $99 \%$ & 10 & $\mathrm{E}$ & 5 & 2 & $97 \%$ \\
\hline 4 & 196.49445 & $1.521 \mathrm{E}-25$ & $1.5 \mathrm{E}-26$ & 9.8 & 7.4 & 1729.80843 & $\mathrm{H} 1$ & $\mathrm{R}$ & 9 & $\mathrm{~F} 2$ & 2 & 2 & $99 \%$ & 10 & F1 & 7 & 2 & $97 \%$ \\
\hline 2 & 200.41326 & $7.569 \mathrm{E}-26$ & $6.6 \mathrm{E}-27$ & 8.8 & 7.2 & 1979.42855 & $\mathrm{H} 1$ & $\mathrm{R}$ & 11 & $\mathrm{~F} 1$ & 4 & 2 & $93 \%$ & 12 & $\mathrm{~F} 2$ & 0 & 2 & $99 \%$ \\
\hline 2 & 200.41852 & $7.373 \mathrm{E}-26$ & $5.1 \mathrm{E}-27$ & 6.8 & 4.2 & 1979.38906 & $\mathrm{H} 1$ & $\mathrm{R}$ & 11 & $\mathrm{~F} 2$ & 3 & 2 & $93 \%$ & 12 & $\mathrm{~F} 1$ & 9 & 2 & $99 \%$ \\
\hline 4 & 208.5 & 3.62 & $9.2 \mathrm{E}-27$ & 2.5 & -1.5 & 1826.21678 & $\mathrm{H} 1$ & $\mathrm{R}$ & 10 & $\mathrm{~A} 1$ & 1 & 2 & $98 \%$ & 11 & $\mathrm{~A} 2$ & 2 & & $92 \%$ \\
\hline 4 & 208. & 2.23 & $1.6 \mathrm{E}-26$ & 7.2 & 5.6 & 1826.33783 & $\mathrm{H} 1$ & $\mathrm{R}$ & 10 & $\mathrm{~F} 1$ & 1 & 2 & $98 \%$ & 11 & F2 & 6 & 2 & $92 \%$ \\
\hline 4 & 209.48148 & $2.040 \mathrm{E}-25$ & $1.7 \mathrm{E}-26$ & 8.4 & 3.7 & 1826.49407 & $\mathrm{H} 1$ & $\mathrm{R}$ & 10 & $\mathrm{~F} 2$ & 1 & 2 & $98 \%$ & 11 & $\mathrm{~F} 1$ & 7 & 2 & $92 \%$ \\
\hline 4 & 210.08444 & $3.147 \mathrm{E}-25$ & $8.1 \mathrm{E}-27$ & 2.6 & 2.0 & 1826.88440 & $\mathrm{H} 1$ & $\mathrm{R}$ & 10 & $\mathrm{~A} 2$ & 1 & 2 & $98 \%$ & 11 & $\mathrm{~A} 1$ & 3 & 2 & $93 \%$ \\
\hline 4 & 213.2 & $1.529 \mathrm{E}-25$ & $7.4 \mathrm{E}-27$ & 4.8 & -1.0 & 1827.29191 & $\mathrm{H} 1$ & $\mathrm{R}$ & 10 & $\mathrm{~F} 2$ & 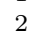 & 2 & $98 \%$ & 11 & $\mathrm{~F} 1$ & 8 & 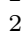 & $95 \%$ \\
\hline 3 & 213. & 1.06 & $1.1 \mathrm{E}-26$ & 10. & 3.1 & 1827.39616 & $\mathrm{H} 1$ & $\mathrm{R}$ & 10 & $\mathrm{E}$ & 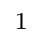 & 2 & $98 \%$ & 11 & $\mathrm{E}$ & 5 & & $95 \%$ \\
\hline 1 & 214 & 5.64 & $1.5 \mathrm{E}-27$ & 2.7 & 0.7 & 1350.69110 & $\mathrm{H} 2$ & $\mathrm{Q}$ & 2 & A1 & 1 & 2 & $99 \%$ & 2 & $\mathrm{~A} 2$ & 1 & 1 & $100 \%$ \\
\hline 4 & 215.51504 & $9.341 \mathrm{E}-26$ & $6.5 \mathrm{E}-27$ & 6.9 & -10 . & 1828.82669 & H1 & $\mathrm{R}$ & 10 & $\mathrm{~F} 1$ & 2 & 2 & $99 \%$ & 11 & $\mathrm{~F} 2$ & 7 & 2 & $96 \%$ \\
\hline 4 & 216.06227 & 1.04 & $1.1 \mathrm{E}-26$ & 10. & 3.0 & 1828. & $\mathrm{H} 1$ & $\mathrm{R}$ & 10 & $\mathrm{~F} 2$ & 3 & 2 & $99 \%$ & 11 & $\mathrm{~F} 1$ & 9 & 2 & $97 \%$ \\
\hline 4 & 226.08668 & 1.63 & $2.2 \mathrm{E}-26$ & 13. & 5.4 & 1935.10815 & $\mathrm{H} 1$ & $\mathrm{R}$ & 11 & $\mathrm{~F} 1$ & 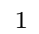 & 2 & $98 \%$ & 12 & $\mathrm{~F} 2$ & 7 & 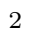 & $90 \%$ \\
\hline 4 & 226 . & 9.40 & $1.7 \mathrm{E}-26$ & 19. & -5.3 & 179 & $\mathrm{H} 1$ & $\mathrm{R}$ & 11 & $\mathrm{E}$ & 1 & 2 & $98 \%$ & 12 & $\mathrm{E}$ & 5 & & $91 \%$ \\
\hline 3 & 227.0 & 1.44 & $6.3 \mathrm{E}-27$ & 4.4 & 4.6 & 1935.41678 & H1 & $\mathrm{R}$ & 11 & $\mathrm{~F} 2$ & 1 & 2 & $98 \%$ & 12 & F1 & 7 & 2 & $91 \%$ \\
\hline 3 & 231.61144 & 1.136 & $1.4 \mathrm{E}-26$ & 13. & 6.8 & 1936.35196 & $\mathrm{H} 1$ & $\mathrm{R}$ & 11 & $\mathrm{~F} 2$ & 2 & 2 & $98 \%$ & 12 & F1 & 8 & 2 & $94 \%$ \\
\hline 4 & 232.40061 & $1.176 \mathrm{E}-25$ & $1.6 \mathrm{E}-26$ & 13. & 11. & 1936.53105 & $\mathrm{H} 1$ & $\mathrm{R}$ & 11 & $\mathrm{~F} 1$ & 2 & 2 & $98 \%$ & 12 & $\mathrm{~F} 2$ & 8 & 2 & $94 \%$ \\
\hline 4 & 234.60288 & 1.240 & $1.8 \mathrm{E}-26$ & 15. & 5.5 & 1938.19333 & $\mathrm{H} 1$ & $\mathrm{R}$ & 11 & A1 & 1 & 2 & $99 \%$ & 12 & $\mathrm{~A} 2$ & 3 & & $96 \%$ \\
\hline 2 & 235. & 6.22 & $1.4 \mathrm{E}-26$ & 23. & -9.6 & 1938 & $\mathrm{H} 1$ & $\mathrm{R}$ & 11 & $\mathrm{~F} 1$ & 3 & 2 & $99 \%$ & 12 & $\mathrm{~F} 2$ & 9 & 2 & $96 \%$ \\
\hline 2 & 235.2 & 4.59 & $1.8 \mathrm{E}-26$ & 40. & 0.1 & 1938.25388 & $\mathrm{H} 1$ & $\mathrm{R}$ & 11 & $\mathrm{E}$ & 2 & 2 & $99 \%$ & 12 & $\mathrm{E}$ & 6 & 2 & $96 \%$ \\
\hline 4 & 243.05250 & $1.100 \mathrm{E}-25$ & $9.2 \mathrm{E}-27$ & 8.4 & 5.9 & 2054.25035 & $\mathrm{H} 1$ & $\mathrm{R}$ & 12 & $\mathrm{~F} 2$ & 1 & 2 & $97 \%$ & 13 & F1 & 7 & 2 & $89 \%$ \\
\hline 4 & 243.45937 & $7.103 \mathrm{E}-26$ & $1.2 \mathrm{E}-26$ & 17. & 6.9 & 2054.33826 & $\mathrm{H} 1$ & $\mathrm{R}$ & 12 & $\mathrm{E}$ & 1 & 2 & $97 \%$ & 13 & $\mathrm{E}$ & 5 & 2 & $89 \%$ \\
\hline 4 & 243 & 1.08 & $1.1 \mathrm{E}-26$ & 10. & 13. & 2054. & $\mathrm{H} 1$ & $\mathrm{R}$ & 12 & F1 & 1 & 2 & $98 \%$ & 13 & F2 & 8 & 2 & $89 \%$ \\
\hline 3 & 248.7 & 7.71 & $1.1 \mathrm{E}-26$ & 14 . & -5.4 & 2055.08303 & $\mathrm{H} 1$ & $\mathrm{R}$ & 12 & $\mathrm{~F} 2$ & 2 & 2 & $98 \%$ & 13 & $\mathrm{~F} 1$ & 8 & 2 & $92 \%$ \\
\hline 1 & 250.14194 & 4.01 & $1.9 \mathrm{E}-27$ & 4.6 & -13 & 2055.82977 & H1 & $\mathrm{R}$ & 12 & $\mathrm{E}$ & 2 & 2 & $98 \%$ & 13 & $\mathrm{E}$ & 6 & 2 & $93 \%$ \\
\hline 2 & 250.73599 & $6.427 \mathrm{E}-26$ & $1.4 \mathrm{E}-26$ & 21. & -4.9 & 2055.91682 & $\mathrm{H} 1$ & $\mathrm{R}$ & 12 & $\mathrm{~F} 1$ & 2 & 2 & $98 \%$ & 13 & $\mathrm{~F} 2$ & 9 & 2 & $94 \%$ \\
\hline 4 & 251.65046 & $1.089 \mathrm{E}-25$ & $2.2 \mathrm{E}-26$ & 20. & -2.2 & 2056.05538 & $\mathrm{H} 1$ & $\mathrm{R}$ & 12 & $\mathrm{~A} 1$ & 1 & 2 & $98 \%$ & 13 & $\mathrm{~A} 2$ & 4 & 2 & $94 \%$ \\
\hline 4 & 259.4 & $1.1:$ & $9.7 \mathrm{E}-27$ & 8.5 & 3.6 & 2183.60734 & $\mathrm{H} 1$ & $\mathrm{R}$ & 13 & A2 & 1 & 2 & $97 \%$ & 14 & $\mathrm{~A} 1$ & 3 & 2 & $87 \%$ \\
\hline 2 & 259.82624 & $6.418 \mathrm{E}-26$ & $8.8 \mathrm{E}-27$ & 14 . & 0.5 & 2183.69686 & $\mathrm{H} 1$ & $\mathrm{R}$ & 13 & $\mathrm{~F} 2$ & 1 & 2 & $97 \%$ & 14 & $\mathrm{~F} 1$ & 8 & 2 & $87 \%$ \\
\hline 4 & 260.79244 & $1.053 \mathrm{E}-25$ & $8.1 \mathrm{E}-27$ & 7.7 & 5.6 & 2184.03721 & H1 & $\mathrm{R}$ & 13 & A1 & 1 & 2 & $97 \%$ & 14 & $\mathrm{~A} 2$ & 3 & 2 & $88 \%$ \\
\hline 1 & 266.24801 & $5.998 \mathrm{E}-26$ & $1.7 \mathrm{E}-27$ & 2.8 & 22 . & 2184.55750 & $\mathrm{H} 1$ & $\mathrm{R}$ & 13 & $\mathrm{~F} 1$ & 2 & 2 & $97 \%$ & 14 & $\mathrm{~F} 2$ & 9 & 2 & $91 \%$ \\
\hline 2 & 268.76924 & $3.890 \mathrm{E}-26$ & $1.6 \mathrm{E}-26$ & 41. & -4.9 & 2185.60083 & $\mathrm{H} 1$ & $\mathrm{R}$ & 13 & $\mathrm{~F} 2$ & 2 & 2 & $98 \%$ & 14 & $\mathrm{~F} 1$ & 9 & 2 & $93 \%$ \\
\hline 2 & 269 . & 4.17 & $9.7 \mathrm{E}-27$ & 23. & 4.7 & & $\mathrm{H} 1$ & $\mathrm{R}$ & 13 & $\mathrm{~F} 1$ & 3 & 2 & $98 \%$ & 14 & F2 & 0 & 2 & $93 \%$ \\
\hline 3 & 273.44688 & $4.447 \mathrm{E}-26$ & $5.1 \mathrm{E}-27$ & 12 . & 4.2 & 2187.85038 & H1 & $\mathrm{R}$ & 13 & A2 & 2 & 2 & $98 \%$ & 14 & A1 & 4 & 2 & $95 \%$ \\
\hline 1 & 275.81160 & $3.924 \mathrm{E}-26$ & $1.2 \mathrm{E}-27$ & 3.2 & 3.5 & 2323.29696 & H1 & $\mathrm{R}$ & 14 & $\mathrm{~F} 2$ & 1 & 2 & $97 \%$ & 15 & $\mathrm{~F} 1$ & 9 & 2 & $85 \%$ \\
\hline 1 & 276.24110 & $2.968 \mathrm{E}-26$ & $1.9 \mathrm{E}-27$ & 6.2 & 20 . & 2323.40587 & $\mathrm{H} 1$ & $\mathrm{R}$ & 14 & $\mathrm{E}$ & 1 & 2 & $97 \%$ & 15 & $\mathrm{E}$ & 6 & 2 & $86 \%$ \\
\hline
\end{tabular}




\section{References}

[1] Khalil, M.. Non- $\mathrm{CO}_{2}$ greenhouse gases in the atmosphere. Annu Rev Energy Environ 1999;24:645-661.

[2] Boudon, V., Champion, J.P., Gabard, T., Pierre, G., Loëte, M., Wenger, C.. Spectroscopic tools for remote sensing of greenhouse gases $\mathrm{CH}_{4}, \mathrm{CF}_{4}$ and $\mathrm{SF}_{6}$. Environ Chem Lett 2003;1:86-91.

[3] Formisano, V., Atreya, S., Encrenaz, T., Ignatiev, N., Giuranna, M.. Detection of methane in the atmosphere of Mars. Science 2004;306:17581761.

[4] Irwin, P.G.J., Shira, K., Bowles, N., Taylor, F.W., Calcutt, S.B.. Methane absorption in the atmosphere of Jupiter from 1800 to $9500 \mathrm{~cm}^{-1}$ and implications for vertical cloud structure. Icarus 2005;176:255-271.

[5] Caradini, A., Filacchione, G., Capaccioni, F., Cerroni, P., Adriani, A., Brown, R.H., et al. CASSINI/VIMS-V at Jupiter: Radiometric test and data results. Planetary and Space Science 2004;52:661-670.

[6] Tran, H., Flaud, P.M., Fouchet, T., Gabard, T., Hartmann, J.M.. Model, software and database for line-mixing effects in the $\nu_{3}$ and $\nu_{4}$ bands of $\mathrm{CH}_{4}$ and tests using laboratory and planetary measurements. II. $\mathrm{H}_{2}$ (and $\mathrm{He}$ ) broadening and the atmosphere of Jupiter and Saturn. J Quant Spectrosc Radiat Transfer 2006;101(2):306-324.

[7] Coustenis, A., Salama, A., Schulz, B., Lellouch, E., Encrenaz, T., Ott, S., et al. Past and future space observations of Titan in the infrared and submm ranges: ISO, Cassini and FIRST. In: Pilbratt, G.L., Cernicharo, J., Heras, A.M., Harris, R., editors. The promise of the Herschel Space Observatory, 12-15 Decemer 200, Toledo, Spain; vol. SP-460. ESA; 2001,.

[8] Griffith, C.A., Penteado, P., Rannou, P., Brown, R., Boudon, V., Baines, K.H., et al. Evidence for a polar ethane cloud on Titan. Science 2006;313:1620-1622.

[9] Coustenis, A., Negrão, A., Salama, A., Schulz, B., Lellouch, E., Rannou, P., et al. Titan's 3-micron spectral region from ISO high-resolution spectroscopy. Icarus 2006;180:176-185.

[10] Negrão, A., Coustenis, A., Lellouch, E., Maillard, J.P., Rannou, P., Schmitt, B., et al. Titan's surface albedo variations over a Titan season from near-infrered CFHT/FTS spectra. Planetary and Space Science 2006;54:1225-1246.

[11] Negrão, A., Hirtzig, M., Coustenis, A., Gendron, E., Drossart, P., Rannou, P., et al. 2-micron spectroscopy of Huygens probe landing site on Titan with VLT/NACO. J Geophys Res 2007;112:E02S92. 
[12] Sromovsky, L.A., Fry, P.. The methane abundance and structure of Uranus' cloud bands inferred from spatially resolved 2006 Keck grism spectra. Icarus 2008;193(1):252-266.

[13] Orton, G.S., Encrenaz, T., Leyrat, C., Puetter, R., Friedson, A.J.. Evidence for methane escape and strong seasonal and dynamical perturbations of Neptune's atmospheric temparatures. Astron Astrophys 2007;473(1):L5L8.

[14] Stansberry, J.A., Spencer, J.R., Schmitt, B., Benchkoura, A.I., Yelle, R.V., Lunine, J.I.. A model for the overabundance of methane in the atmospheres of Pluto and Triton. Planetary and Space Science 1996;44(9):10511063 .

[15] Lellouch, E., Sicardy, B., de Bergh, C., Kaeufl, H.U., Kassi, S., Campargue, A.. Pluto's lower atmosphere structure and methane abundance from high-resolution spectroscopy and stellar occultations. Astron Astrophys 2009;495:L17-L21.

[16] Swain, M.R., Vasisht, G., Tinetti, G.. The presence of methane in the atmosphere of an extrasolar planet. Nature 2008;452:329-331.

[17] Swain, M.R., Tinetti, G., Vasisht, G., Deroo, P., Griffith, C., Bouwman, J., et al. Water, methane, and carbon dioxide present in the dayside spectrum of the exoplanet HD 209458b. Astrophys J 2009;704:1616-1621.

[18] Villanueva, G.L., Mumma, M.J., Novak, R.E.. Strong release of methane on Mars: Evidence of biology or geology? Geochim Cosmochim Acta 2009;73:A1384-A1384.

[19] Lefèvre, F., Forget, F.. Observed variations of methane on Mars unexplained by known atmospheric chemistry and physics. Nature 2009;460:720-723.

[20] Jennings, D.E., Romani, P.N., Bjoraker, G.L., Sada, P.V., Nixon, C.A., Lunsford, A.W., et al. ${ }^{12} \mathrm{C} /{ }^{13} \mathrm{C}$ ratio in ethane on Titan and implications for methane's replenishment. J Phys Chem A 2009;113:11101-11106.

[21] Suits, A.G.. Titan: A strangely familiar world. J Phys Chem A 2009;113:11097-11098.

[22] Coustenis, A., Achterberg, R.K., Conrath, B.J., Jennings, D.E., Marten, A., Gautier, D., et al. The composition of Titan's stratosphere from Cassini/CIRS mid-infrared spectra. Icarus 2007;189(35-62).

[23] Hilico, J., Loëte, M., Champion, J., Destombes, J., Bogey, M.. The millimeter-wave spectrum of methane. J Mol Spectrosc 1987;122:381-389. 
[24] Oldani, M., Andrist, M., Bauder, A., Robiette, A.G.. Pure rotational spectra of methane and methane- $d_{4}$ in the vibrational ground state observed by microwave fourier transform spectroscopy. J Mol Spectrosc 1985;110:93-105.

[25] Wishnow, E.H., Orton, G.S., Ozier, I., Gush, H.P.. The distorsion dipole rotational spectrum of $\mathrm{CH}_{4}$ : A low temperature far-infrared study. J Quant Spectrosc Radiat Transfer 2007;103:102-117.

[26] Rothman, L.S., Gordon, I.E., Barbe, A., Benner, D.C., Bernath, P.F., Birk, M., et al. The HITRAN 2008 molecular spectroscopic database. J Quant Spectrosc Radiat Transfer 2009;110:533-572.

[27] McKellar, A.R.W.. Private communication; 1988.

[28] Ozier, I.. Ground-state electric dipole moment of methane. Phys Rev Lett 1971;27(20):1329-1332.

[29] Roy, P., Rouzières, M., Qi, Z.M., Chubar, O.. The AILES infrared beamline on the third generation Synchrotron Radiation Facility SOLEIL. Infrared Physics and Technology 2006;49:139-146.

[30] Brubach, J.B., Manceron, L., Rouzires, M., Pirali, O., Balcon, D., Tchana, F.K., et al. Performance of the AILES THz-infrared beamline on SOLEIL for high resolution spectroscopy. vol. in press. AIP Conference Proceedings; 2009,

[31] Davis, S.P., Abrams, M.C., Brault, J.W.. Fourier transform spectrometry. 2001.

[32] Wells, R.J.. Rapid approximation to the Voigt/Faddeeva function and its derivatives. J Quant Spectrosc Radiat Transfer 1999;62:29-48.

[33] Carleer, M.R.. WSpectra: a Windows program to accurately measure the line intensities of high-resolution Fourier transform spectra. In: Remote sensing of clouds and the atmosphere V; vol. 4168. Barcelona, Spain: Proceedings of SPIE - The International Society for Optical Engineering; 2001, p. 337 .

[34] Predoi-Cross, A., Brown, L.R., Devi, V.M., Brawley-Tremblay, M., Benner, D.C.. Multispectrum analysis of ${ }^{12} \mathrm{ch}_{4}$ from 4100 to $4635 \mathrm{~cm}^{-1}$ : 1 . selfbroadening coefficients (widths and shifts). J Mol Spectrosc 2005;232:231246.

[35] Champion, J.P., Loëte, M., Pierre, G.. Spherical top spectra. In: Rao, K.N., Weber, A., editors. Spectroscopy of the Earth's atmosphere and interstellar medium. San Diego: Academic Press; 1992, p. 339-422. 
[36] Boudon, V., Champion, J.P., Gabard, T., Loëte, M., Michelot, F., Pierre, G., et al. Symmetry-adapted tensorial formalism to model rovibrational and rovibronic spectra of molecules pertaining to various point groups. J Mol Spectrosc 2004;228:620-634.

[37] Albert, S., Bauerecker, S., Boudon, V., Brown, L., Champion, J.P., Loëte, M., et al. Global analysis of the high resolution infrared spectrum of methane ${ }^{12} \mathrm{CH}_{4}$ in the region from 0 to $4800 \mathrm{~cm}^{-1}$. Chem Phys 2009;356:131-146.

[38] Mills, I.M., Watson, J.K.G., Smith, W.L.. Rotational spectra induced by vibrations. Mol Phys 1969;16(4):329-344.

[39] Prinz, H., Höhe, W., Kreiner, W.A., Loëte, M., Hilico, J.C., Pierre, G., et al. The vibration-induced dipole moment in the $\nu_{2} \nu_{4}$ dyad of ${ }^{13} \mathrm{~cd}_{4}$ and ${ }^{28}$ sih $_{4}$. J Mol Spectrosc 1989;135:144-160.

[40] Mourbat, A., Boumajd, A., Loëte, M.. Simultaneous determination of force constants and dipole moment derivatives of methane. J Mol Spectrosc 1998;190:198-212.

[41] Ozier, I., Rosenberg, A.. The vibrationally induced rotational spectrum of $\mathrm{ch}_{4}$ in the $\left(v_{4}=1\right)$ state. J Chem Phys 1978;69(11):5203-5204.

[42] Rothman, L.S., Jacquemart, D., Barbe, A., Benner, D.C., Birk, M., Brown, L.R., et al. The HITRAN 2004 molecular spectroscopic database. J Quant Spectrosc Radiat Transfer 2005;96:139-204.

[43] Benner, D.C., Rinsland, C.P., Devi, V.M., Smith, M.A.H., Atkins, D.. A multispectrum nonlinear least squares fitting technique. J Quant Spectrsoc Radiat Transfer 1995;53:705-21. 